\title{
On the Pardosa monticola species-group (Araneae: Lycosidae) from Middle Asia
}

\section{О видах группы Pardosa monticola (Araneae: Lycosidae) из Средней Азии}

\author{
Francesco Ballarin ${ }^{1,2}$, Yuri M. Marusik ${ }^{2,3}$, Mikhail M. Omelko ${ }^{2,4,5}$ \\ and Seppo Koponen ${ }^{2}$ \\ Ф. Бамларин ${ }^{1,2}$, Ю.М. Марусик ${ }^{2,3}$, М.М. Омемько ${ }^{2,4,5}$, С. Копонен ${ }^{2}$
}

\footnotetext{
${ }^{1}$ Museo Civico di Storia Naturale di Verona, Lungadige Porta Vittoria, 9 - 37129, Verona, Italy. E-mail: ballarin.francesco@gmail.com ${ }^{2}$ Zoological Museum, University of Turku, FI-20014, Turku, Finland; e-mail: sepkopo@utu.fi

${ }^{3}$ Institute for Biological Problems of the North of the Russian Academy of Sciences, Portovaya Str. 18, 685000 Magadan, Russia. E-mail: yurmar@mail.ru

${ }^{4}$ Far Eastern Federal University, Sukhanova, 8, Vladivostok 690950, Russia

${ }^{5}$ Gornotaezhnaya Station FEB RAS, Gornotaezhnoe Vil., Ussuriyski Dist., Primorski Krai 692533, Russia. E-mail: omelkom@gmail.com

${ }^{1}$ Государственный музей естественной истории, Lungadige Porta Vittoria, 9 - 37129, Верона, Италия.

${ }^{2}$ Зоологический музей, университет Турку, FI-20014 Турку, Финляндия.

${ }^{3}$ Институт Биологических Проблем Севера ДВО РАН, ул. Портовая 18, Магадан 685000, Россия.

${ }^{4}$ Дальневосточный Федеральный университет, Суханова 8, Владивосток 690950, Россия

${ }_{5}^{5}$ Горнотаёжная станция ДВО РАН, с. Горнотаёжное, Уссурийский район, Приморский край 692533, Россия.
}

KEY WORDS: Middle Asia, Central Asia, wolf spider, monticola-group, new species.

КЛЮЧЕВЫЕ СЛОВА: Средняя Азия, Центральная Азия, пауки-волки, группа monticola, новые виды.

ABSTRACT. The Pardosa monticola-group from Middle Asian countries (southern Kazakhstan, Kyrgyzstan, Tajikistan, Turkmenistan and Uzbekistan) is revised. Among the material studied we recognized eight morphospecies, seven of which are new to science: $P$. fritzeni sp.n. ( $\sigma^{\prime}+$, Kyrgyzstan), P. zonsteini sp.n. ( ${ }^{\top}+$, Kazakhstan, Kyrgyzstan, Uzbekistan), $P$. ovtchinnikovi sp.n. (O'O, Tajikistan, Turkmenistan, Uzbekistan), P. trottai sp.n. ( $\sigma^{\top} O$, Kyrgyzstan), $P$. mikhailovi sp.n. ( $\sigma^{7}$, Kazakhstan), P. gromovi sp.n. ( $\sigma^{\top}+$, Kazakhstan) and $P$. pantinii sp.n. ( $\sigma^{\top}$, , Tajikistan). All known species from Middle Asia, including the single named species $P$. pontica (Thorell, 1875) from western Turkmenistan and two species from adjacent countries: P. pseudomixta Marusik et Fritzén, 2009 (Xinjiang, China) and $P$. pseudotorrentum Miller et Buchar, 1972 (Hindu-Kush, northern Afghanistan) are illustrated. Male palps of Middle Asian species are very similar to each other but males of the different species can be easily identified by their general habitus or their first pair of legs in terms of colour, pubescence, relative length and spination. Females are not easily separated due to a lack of diagnostic characters and considerable intraspecific variation. Keys to the males of the 10 species treated in this paper are provided.

РЕЗЮМЕ. Ревизована группа видов Pardosa monticola из стран Средней Азии (южный Казахстан, Киргизстан, Таджикистан, Туркменистан и Узбекистан). В изученном материале распознано восемь морфовидов, семь из которых новые для науки: P. fritzeni sp.n. ( $\sigma^{\top}+$, Киргизстан), P. zonsteini sp.n. (O’ + , Казахстан, Киргизстан, Узбекистан), $P$. ovtchinnikovi sp.n. ( $\sigma^{7}$, Таджикистан, Туркменистан, Узбекистан), P. trottai sp.n. (О'O, Киргизстан), P. mikhailovi sp.n. ( $\sigma^{7}$, Казахстан), P. gromovi sp.n. $\left(\sigma^{\top}+\right.$, Казахстан) и $P$. pantinii sp.n. ( $\sigma^{\top}+$, Таджикистан). Проиллюстрированы все виды из Средней Азии, включая единственный известный ранее вид P. pontica (Thorell, 1875) из западного Таджикистана, а также два вида из сопредельных стран: $P$. pseudomixta Marusik et Fritzén, 2009 (Синьцзян, Китай) и P. pseudotorrentum Miller et Buchar, 1972 (Гиндукуш, северный Афганистан). Пальпы самцов среднеазиатских видов очень похожи друг на друга, но самцы хорошо отличаются по габитусу, а также окраске ноги I, ее опушению, сравнительной длине и шипованию. Самки, напротив, трудно различимы из-за недостатка диагностических признаков и большой вариабельности в пределах вида. Приводится определительный ключ для всех 10 видов, обсуждаемых в работе.

\section{Introduction}

Pardosa C.L. Koch, 1847 with 549 species [Platnick, 2012] is the largest genus of Lycosidae, with its highest species diversity in the Holarctic and South East Asia. Pardosa is relatively well studied in the Nearctic, Europe, Japan and China. Most of the north 
Holarctic species have been assigned into distinct species-groups based on shared characteristics of the copulatory organs [e.g. Zyuzin, 1979; Dondale \& Redner, 1990] but no taxonomic division of the genus has been proposed. The largest species-group within Pardosa is the P. nebulosa-group [Marusik \& Ballarin, 2011], which includes at least 66 species. The second largest is the $P$. monticola species-group with about 25 valid names [Marusik \& Fritzén, 2009]. Although this group has a Holarctic distribution it clearly has a Palaearctic origin. Only one species, $P$. palustris (Linnaeus, 1758) reaches the Nearctic. Of 25 species belonging to this group only 4 species are not known in the Western Palaearctic: P. pseudomixta Marusik et Fritzén, 2009, P. pseudotorrentum Miller et Buchar, 1972, P. condolens (O. Pickard-Cambridge, 1885) and $P$. fortunata (O. Pickard-Cambridge, 1885).

Although a few species have wide ranges, most of the species in this group have a local distribution. West Palaearctic species have been treated comprehensively in numerous publications, the most important of which are Tongiorgi [1966a,b] and Zyuzin \& Logunov [2000].

So far eight species belonging to the Pardosa monticola-group have been reported from the Middle Asian republics: $P$. agrestis (Westring, 1861), $P$. agricola (Thorell, 1856), P. condolens, P. fortunata, P. mixta (Kulczyński, 1887), P. palustris, P. pontica (Thorell, 1875) and $P$. plumipes (Thorell, 1875) [Mikhailov, 1997; Platnick, 2012]. Of these, only three species have been treated in taxonomic works: $P$. condolens and $P$. fortunata by O. Pickard-Cambridge [1885] and $P$. pontica by Zyuzin \& Logunov [2000]. The remaining five species were mentioned in several faunistic publications.

While working on a paper dealing with $P$. mixta and P. pseudomixta [Marusik \& Fritzén, 2009] it was found that the records of $P$. mixta from Uzbekistan [Charitonov, 1969] were based on misidentifications and that the specimens from Uzbekistan may belong to a new species. Recently we got the opportunity to study some Middle Asian lycosids. Among them we found approximately 160 specimens of Pardosa belonging to the monticola-group from South Kazakhstan, Kyrgyzstan, Tajikistan, Turkmenistan and Uzbekistan. Study of this material revealed at least eight male morphospecies and more morphospecies if females are considered. Most of them are related to P. mixta (endemic to the Alps) and closely related to P. pseudomixta (known from Xinjiang) and $P$. pseudotorrentum (known from Afghanistan). Although the structure of the palp in males of these species is very similar and sometimes almost indistinguishable, they have clear differences in their habitus, the first pair of legs (colour, shape and plumage of metatarsus-tarsus and spination) (Figs 39-63, 98-106), size of carapace and palp coloration.

However, females are almost indistinguishable because of their similarity in habitus and epigynal shape. In addition, there is a large intraspecific variation in the shape of epigyne, as usually occurs in this speciesgroup [cf. Tongiorgi, 1966b]. Nevertheless, we tried to assign females to every species described in this paper based on their collection localities and the presence of males in the same samples or in adjacent localities. Only in a few cases, P. trottai sp.n., P. gromovi sp.n., $P$. pantinii sp.n. and $P$. pontica, it was possible to find sufficient clear diagnostic characters, useful for identification of the females. A thorough study of females falls outside the purpose of this paper, the main goals of which are to provide descriptions of the newly discovered species and compare the males with those of $P$. pontica, $P$. pseudomixta and $P$. pseudotorrentum.

\section{Material and methods}

Specimens and copulatory organs were photographed using an Olympus SZX16 stereomicroscope with an Olympus E-520 camera. Photographs were taken in dishes of different sizes with paraffin at the bottom. Different sized holes were made in the bottom to keep the specimens in the correct position. The images were generated using "CombineZP" image stacking software. Scanning electron micrographs were prepared using a SEM JEOL JSM-5200 scanning microscope belonging to the Zoological Museum, University of Turku. Left legs I and left palps are shown, when this was not possible ( $P$. ovtchinnikovi sp.n. and $P$. gromovi sp.n.) the right palp was photographed and digitally reversed for a better comparison. Spination of leg I was examined in all species and specimens with the exception of $P$. mikhailovi sp.n and $P$. pseudomixta females because of lack of samples. Apical spines of the tibia and metatarsus were not considered because of difficulties in defining their correct positions. We paid attention to the first pair of legs only because they are used in courtship behavior. Our earlier studies proved that in several cases spination can be used as a character for distinguishing between sibling species. Comparative pictures of $P$. plumipes illustrated here are based on specimens from Mongolia.

All measurements are given in millimetres. When possible, for every species the smallest and biggest sizes are reported.

Holotypes, paratypes and other material examined are held in the following institutions: Department of Zoology, Perm State University, Russia (PSU), Museo Civico di Storia Naturale di Verona, Italy (MSNV), The Manchester Museum, the University of Manchester, United Kingdom (MMUM), Siberian Zoological Museum of Novosibirsk, Russia (SZMN), National Museum, Praha, Czech Republic (NMPR), Zoological Museum of the Moscow State University, Russia (ZMMU), Zoological Museum, University of Turku, Finland (ZMUT), A.V. Gromov personal collection (AGPC).

Most of the material used in this paper was collected by the late S.V. Ovtchinnikov and A.V. Gromov.

Abbreviations used in the figures: $T a$ - tegular apophysis; $T p$ — terminal apophysis. 


\section{Taxonomic survey}

The Pardosa monticola-group seems to have been first recognized by Thorell [1872]. He listed 11 species in this group. Later, the species group was considered in Dahl [1908], Locket \& Millidge [1951], Wiebes [1959], Tongiorgi [1966b] and many other publications. Until now this group has included 25 species [Marusik \& Fritzén, 2009]. P. condolens was assigned to this group by Marusik \& Fritzén [2009] because O. Pickard-Cambridge [1885] compared it with P. agricola, a member of the $P$. monticola-group. Study of the material of $P$. condolens from Iran identified by Roewer [1955], who saw the type series of this species in Oxford, revealed that this species belongs to the $P$. wagleri-group. An additional argument that $P$. condolens belongs to this group was proposed by Zyuzin [1979], who examined specimens from Armenia identified by Schmidt [1895] as P. condolens and found that they also belonged to the $P$. wagleri-group. We tried to examine the types of lycosids described by $\mathrm{O}$. Pickard-Cambridge in 1885 and deposited in Oxford, but they were not found. Given that this species was erroneously assigned to the group, the correct number of species in the $P$. monticola-group is 24 excluding the new species described here. In the same paper, Pickard-Cambridge [1885] described another species, $P$. fortunata from Yarkand, as very closely allied to $P$. condolens. Because of these similarities this species should also be included in the wagleri-group and so is not considered in this paper.

It is worth mentioning that Roewer [1955] described the new genus Pardosops Roewer, 1955 with the type species $P$. pontica (a member of the $P$. monticola-group). Besides this species, he assigned seven additional Palaearctic (P. condolens, P. morosa L. Koch, 1870, $P$. venatica $\mathrm{L}$. Koch, 1882 (= P. cribrata Simon, 1876), $P$. subsordidatula (Strand, 1915), P. vittata (Keyserling, 1863), P. saltuarides (Strand, 1908)) and an Ethiopian species (P. krausi Roewer, 1959), which belong to at least three other distantly related species-groups: proxima, vittata and wagleri. Although Pardosops as delimited by Roewer [1959] was polyphyletic, and soon after the description it was synonymized with Pardosa by Tongiorgi [1966b], the generic name can be used for the P. monticola-group, if (when) Pardosa is split into several genera in the future. Including the new species described in this paper the total number of species in the P. monticola-group is currently 31 .

Key to the males of the Middle Asian Pardosa MONTICOLA-GROUP

1. Tarsus and metatarsus I with long lateral hairs (Figs 49, $50,55,59)$

- Tarsus and metatarsus I without long lateral hairs ........... 3

2. Tarsus I swollen (Figs 52, 59), metatarsus I with lateral hairs as long as the diameter (Figs 50, 59)
- Tarsus I cylindrical (Figs 53, 55), metatarsus I with lateral hairs longer than the diameter (Figs 49, 55)...

P. zonsteini sp.n.

3. Tarsus I partially or totally black (Figs $39,46,48$ and 54, $61,63)$

- Tarsus I yellowish or brownish, without black coloration

4. Both tarsus and metatarsus I uniformly black in colour (Figs 39, 54) ..................................... P. fritzeni sp.n.

- Only tip or half of tarsus I black in color (Figs 46, 48 and $61,63)$

5. Terminal apophysis stout (Figs 67, 79) ............ P. pontica

- Terminal apophysis thin (Fig. 92) ............ P. pseudomixta

6. Legs uniformly dark brown (Figs 47,62 ) or dark brown with black femurs and lighter tarsi and metatarsi (Figs

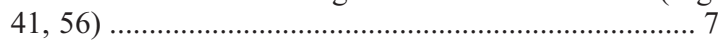

- Legs uniformly yellowish (Figs 42, 45 and 57,60) or, at the most, with a few small dark marks on dorsal side of femurs (Figs 43, 58) ............................................... 8

7. Terminal apophysis thin (Figs 69, 81) .................................. P. ovtchinnikovi sp.n.

- Terminal apophysis stout with a triangular shape (Fig. 28) ................................................. P. pseudotorrentum

8. Palpal patella covered with white hairs (Fig. 36), tarsi I as thin as in other legs ........................... P. pantinii sp.n.

- Palpal patella without white hairs (Figs 33, 34), tarsi I thicker than in other legs ............................................ 9

9. Habitus brown-reddish, abdomen without pattern (Fig. 4), small size (Fig. 125) .............................. P. trottai sp.n.

- Habitus brownish, abdomen with well developed pattern (Fig. 5), bigger size (Fig. 125) ....... P. mikhailovi sp.n.

\section{Species survey}

Pardosa fritzeni sp.n.

Figs 1, 16, 19, 30, 39, 54, 64, 70, 76, 82, 98, 107, $116,125$.

TYPE MATERIAL. Holotype $\sigma^{7}$ and paratype 19 (ZMMU), Kyrgyzstan, Terskey Mountain Range, Aksu River, near Teploklyuchenka Village $\left(42^{\circ} 29^{\prime} 48^{\prime \prime} \mathrm{N} 78^{\circ} 31^{\prime} 36^{\prime \prime} \mathrm{E}\right), 17.06 .1993$ (S.V. Ovtchinnikov). Paratypes: $20^{7} O^{7}$ (ZMMU), same locality, 19.06. 1993 (S.V. Ovtchinnikov); $1 \mathrm{O}^{\top}$ (ZMMU) Ekungey Mountain Range, Santash, basin of Tiup River, $2000 \mathrm{~m}\left(42^{\circ} 45^{\prime} 12.93^{\prime \prime} \mathrm{N} 78^{\circ} 44^{\prime}\right.$ 10.33"E), 5.07.1981 (S.V. Ovtchinnikov).

ETYMOLOGY. The species is named after our friend and colleague Niclas R. Fritzén (Finland) for his contribution to the study of the Pardosa monticolagroup in the Xinjiang Province of China.

DIAGNOSIS. Males of this species can be easily separated from other Middle Asian Pardosa species belonging to the monticola-group by the black tarsus and metatarsus of leg I (Figs 39, 54). Habitus and leg I coloration of $P$. fritzeni sp.n. are distinctly different from those in $P$. pontica, $P$. pseudomixa and $P$. pseudotorrentum. Females of $P$. fritzeni sp.n. are indistinguishable from other females of the monticola-group.

DESCRIPTION. Male. Total length: 5.0-6.85. Carapace: $2.52-3.15$ long, $1.87-2.35$ wide. Carapace dark brown, almost black near the eye field, with a lighter narrow strip surrounding fovea. Lateral bands brownish, unbroken, often poorly visible (Fig. 1). Clypeus yellowish, lighter than cephalic area. Chelicerae brown 


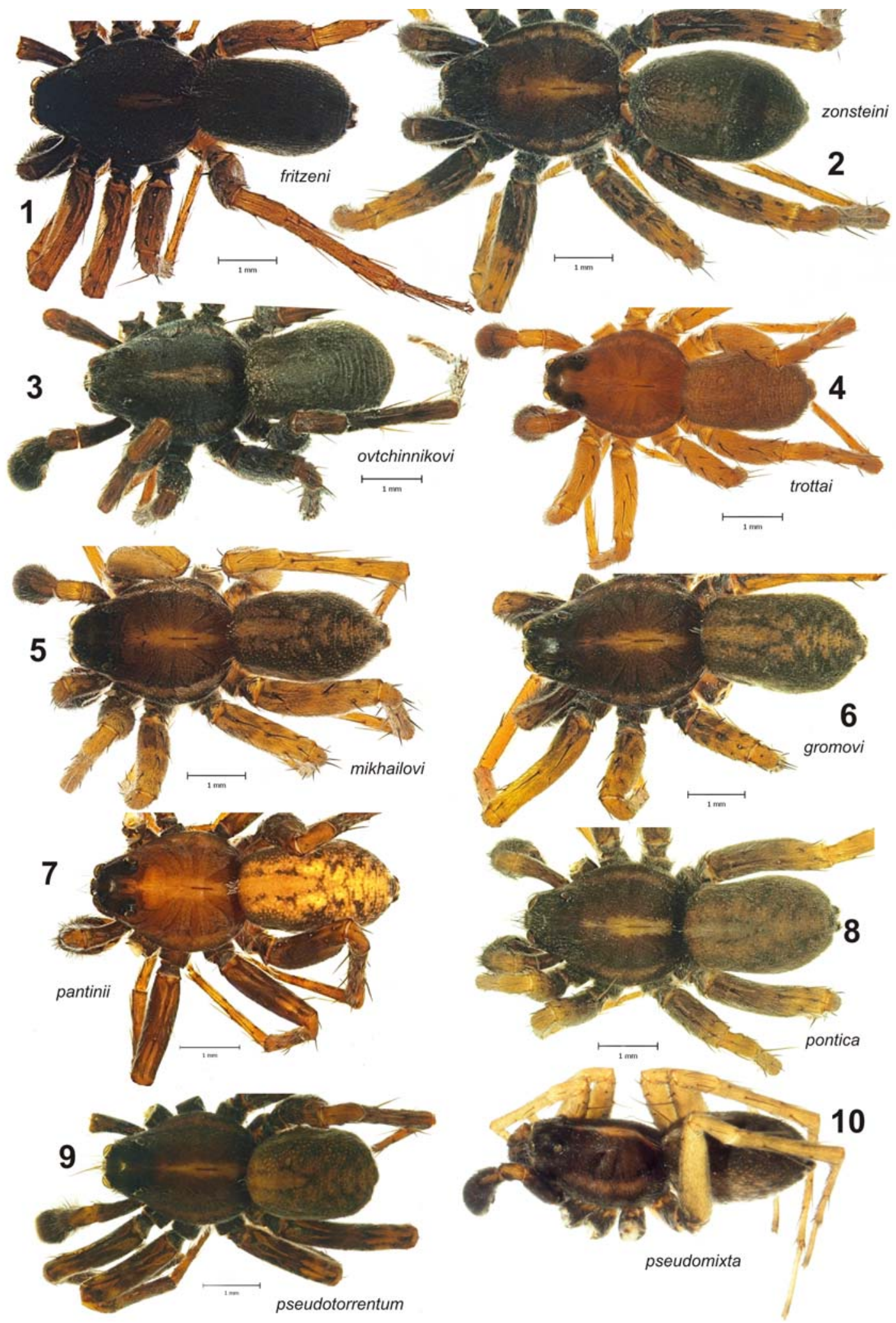

Figs 1-10. Habitus of males of Pardosa fritzeni sp.n. (1), P. zonsteini sp.n. (2), P. ovtchinnikovi sp.n. (3), P. trottai sp.n. (4), P. mikhailovi sp.n. (5), P. gromovi sp.n. (6), P. pantinii sp.n. (7), P. pontica (8), P. pseudotorrentum (9) and P. pseudomixta (10): 10 - after Marusik \& Fritzén [2009], not to scale.

Рис. 1-10. Внешний вид самцов Pardosa fritzeni sp.n. (1), P. zonsteini sp.n. (2), P. ovtchinnikovi sp.n. (3), P. trottai sp.n. (4), P. mikhailovi sp.n. (5), P. gromovi sp.n. (6), P. pantinii sp.n. (7), P. pontica (8), P. pseudotorrentum (9) и P. pseudomixta (10): 10 — по Marusik \& Fritzén [2009], не в масштабе. 


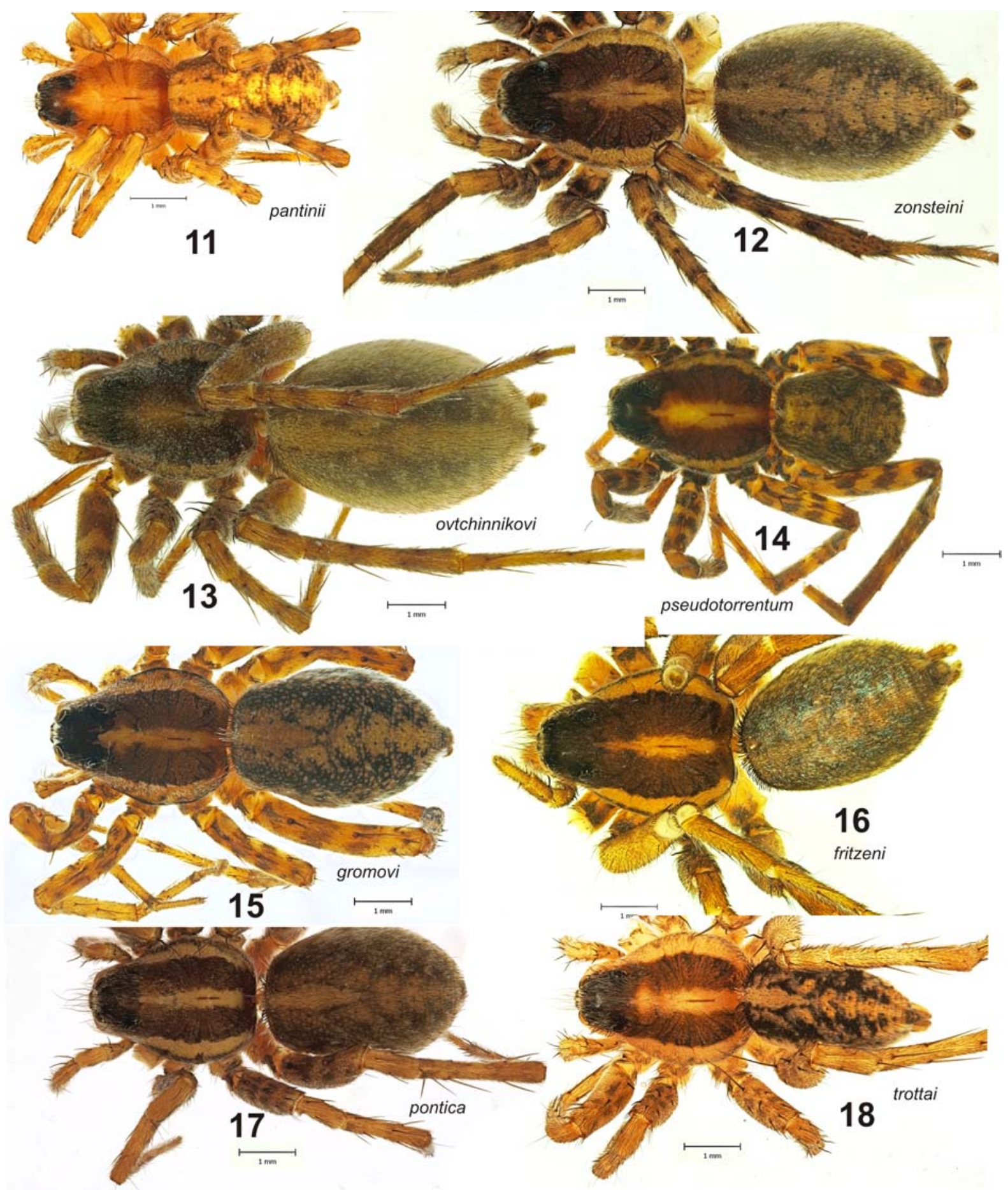

Figs 11-18. Habitus of females of Pardosa pantinii sp.n. (11), P. zonsteini sp.n. (12), P. ovtchinnikovi sp.n. (13), P. pseudotorrentum (14), P. gromovi sp.n. (15), P. fritzeni sp.n. (16), P. pontica (17) and P. trottai sp.n. (18).

Рис. 11-18. Внешний вид самок Pardosa pantinii sp.n. (11), P. zonsteini sp.n. (12), P. ovtchinnikovi sp.n. (13), P. pseudotorrentum (14), P. gromovi sp.n. (15), P. fritzeni sp.n. (16), P. pontica (17) и $P$. trottai sp.n. (18).

with faint, lighter longitudinal stripes. Sternum black. Abdomen dorsally and ventrally as dark as carapace with a faint cardiac mark bordered with black. Legs brownish with darker marks on dorsal side of femur, leg I with tarsus and metatarsus almost black (Figs 39,
54). Leg I length: $2.2+1.0+1.78+1.97+1.27$. Leg I spination: femur d3 p2 r2, patella p1(0) r1(0), tibia p2(1) r2(1) v2-2, metatarsus p1 r1 v2-2. Palp as in Figs 19, $30,64,70,76,82$; black-brown, with lighter patella and tip of cymbium. 


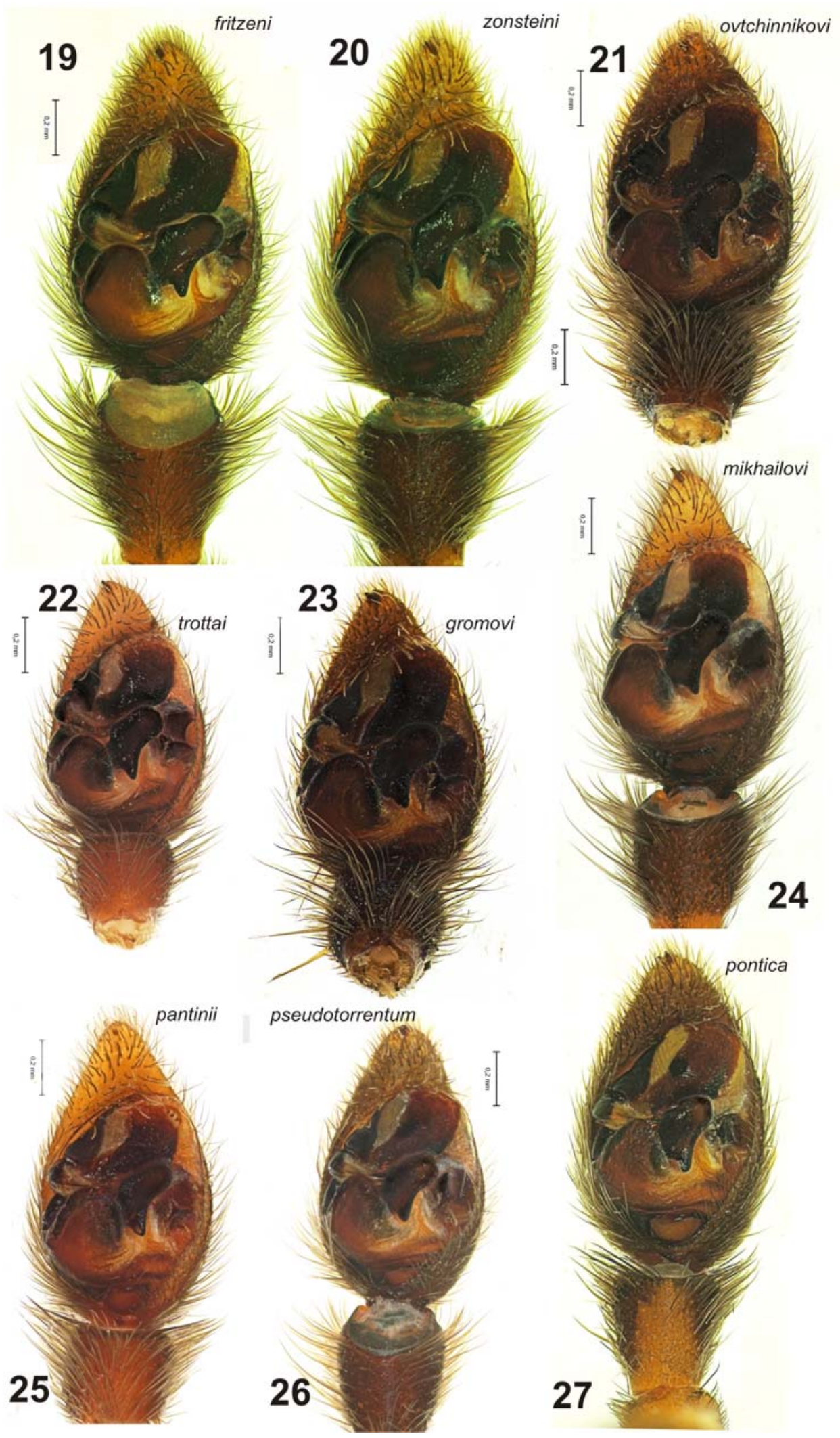

Figs 19-27. Ventral view of male palp of Pardosa fritzeni sp.n. (19), P. zonsteini sp.n. (20), P. ovtchinnikovi sp.n. (21), P. trottai sp.n. (22), P. gromovi sp.n. (23), P. mikhailovi sp.n. (24), P. pantinii sp.n. (25), P. pseudotorrentum (26) and $P$. pontica (27).

Рис. 19-27. Пальпы самцов (вентрально) Pardosa fritzeni sp.n. (19), P. zonsteini sp.n. (20), P. ovtchinnikovi sp.n. (21), P. trottai sp.n. (22), P. gromovi sp.n. (23), P. mikhailovi sp.n. (24), P. pantinii sp.n. (25), P. pseudotorrentum (26) и P. pontica (27). 


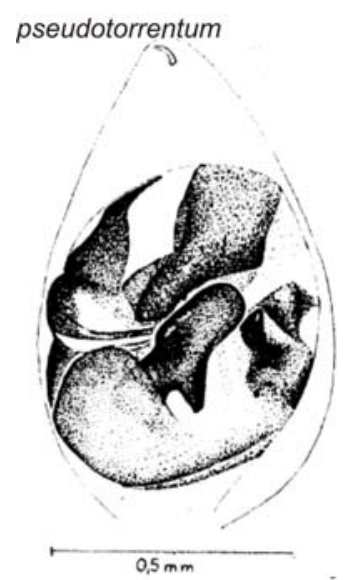

28

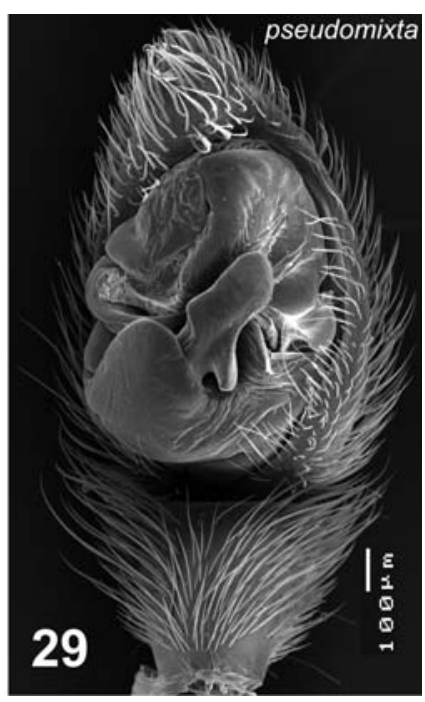

Figs 28-29. Ventral view of male palp of Pardosa pseudotorrentum (28) and P. pseudomixta (29): 28 - after Miller \& Buchar [1972], 29 — after Marusik \& Fritzén [2009].

Рис. 28-29. Вид снизу пальпы самцов Pardosa pseudotorrentum (28) и P. pseudomixta (29): 28 - по Miller \& Buchar [1972], 29 — по Marusik \& Fritzén [2009].

Female. Total length: 7.05. Carapace: 3.35 long, 2.47 wide. Carapace brown with darker area near eye region. Lateral bands continuous, yellow in colour like the median band and separated from carapace margins by a brown stripe (Fig. 16). Clypeus yellow, chelicerae yellowish with faint darker marks. Sternum brownish with two dark stripes united posteriorly. Abdomen dorsally dark brown with a brownish cardiac mark, pairs of spots of the same colour surround and follow the mark. Spots are fused in the posterior half of the abdomen. Ventral side yellow with two lighter longitudinal stripes.

Legs yellow-brownish. Leg I length: $2.57+1.12+$ $1.97+1.9+1.3$. Leg I spination: femur d3 p2 r2, patella p1 r0, tibia p2 r1 v2-2, metatarsus p2 r2 v2-2. Epigyne and vulva as in Figs 107, 116.

DISTRIBUTION. This species is currently known from the mountainous area near the villages of Teploklyuchenka and Santash, north-east Kyrgyzstan (Fig. 126).

\section{Pardosa zonsteini sp.n.}

Figs 2, 12, 20, 31, 40, 49, 53, 55, 66, 72, 78, 84, 103, $108,117,125$.

P. mixta: Charitonov, 1969: 93.

TYPE MATERIAL. Holotype $\sigma^{7}$ (ZMMU) and paratypes $28 \sigma^{7} \sigma^{7} 1$ (ZMMU, MMUM, MSNV), Kyrgyzstan, Inner TienShang, Kokirim Mountain Range, Kaindy (41 $\left.37^{\prime} 15^{\prime \prime} \mathrm{N} 75^{\circ} 9^{\prime} 3^{\prime \prime} \mathrm{E}\right)$, 3.07.199? (S.V. Ovtchinnikov). Paratypes: Kazakhstan, $2 \sigma^{7} \bigcirc^{\prime \prime}$ (ZMMU), Bol'shoye Almaatinskoye Lake, $43^{\circ} 05^{\prime} \mathrm{N} 76^{\circ} 59^{\prime} \mathrm{E}$, 2500 m, 3-10.07.1995. (O.A. Karacheva); $10^{7}$ (AGPC) Zhambyl Area, Merke Valley $\left(42^{\circ} 38^{\prime} 28.41^{\prime \prime} \mathrm{N} 73^{\circ} 15^{\prime} 4.18^{\prime \prime} \mathrm{E}\right), 1.07 .2011$ (I.I. Temreshev). Kyrgyzstan, $1 \sigma^{\top} 1$ (SZMN: SZM 001.4210) Naryn Region, At-Bashy Distr., At-Bashy $\left(41^{\circ} 10^{\prime} 4.85^{\prime \prime} \mathrm{N} 75^{\circ} 48^{\prime} 20.07^{\prime \prime} \mathrm{E}\right)$, gravely and sandy shores, tugai, 17.06 .1987 (A.A. Shileyko); $10^{\circ}$

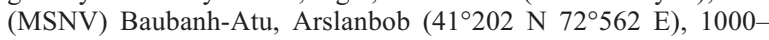

$1800 \mathrm{~m}, 19.05 .1993$, scrub, litter and under stones (S. Golovatch); 2 OT $^{7}$ (ZMUT), Sary-Chelek Reserve (41 402 N, 71 ${ }^{\circ} 562$ E), 1550 $2200 \mathrm{~m}$, forest, 20-31.05.1993 (S. Golovatch); $1 \sigma^{7}$ (ZMMU), Tien-Shang Mountains, Babash-Ata Mountain, ridge near Yarodar, 1400-1700 m, Juglans forest, litter and under bark, 10-17.05.1993 (S. Golovatch); Uzbekistan, $1 \sigma^{7}$ (PSU), Bukhara Area, Yakkabagh (38 58 $\left.47^{\prime \prime} \mathrm{N} 66^{\circ} 41^{\prime} 48^{\prime \prime} \mathrm{E}\right), 24.03 .1942$ (D.M. Fedotov); $2 \sigma^{\prime} \sigma^{\prime}$ (AGPC) Ferghana Area, Yar'yavan Distr., Karakalpak Steppe, ca. $13.5 \mathrm{~km}$ west of Yaz'yavan, Populus forest, ca.400 m, $40^{\circ} 39^{\prime} 01^{\prime \prime} \mathrm{N}$ 71³3'51"E, 19.05.2002 (A.V. Gromov).

ETYMOLOGY. This species is named after our friend and colleague Sergei L. Zonstein (Israel) who has made important contributions to studies of Middle Asian spiders.

DIAGNOSIS. Pardosa zonsteini sp.n. is closely related to $P$. gromovi sp.n. Males of these two species can be separated by the shape of tarsus I, which is long, thin and cylindrical in P. zonsteini sp.n. and short and swollen in P. gromovi sp.n. (cf. Figs 52 and 53). In addition, the lateral hairs of metatarsus I are longer in $P$. zonsteini sp.n. than in $P$. gromovi sp.n. (cf. Figs 49 and 50, 55 and 59).

Males of all other Middle Asian species belonging to the $P$. monticola-group can be easily distinguished from $P$. zonsteini sp.n. by their smaller size and the lack of long lateral hairs on leg I. Females of $P$. zonsteini sp.n. are indistinguishable from other species.

DESCRIPTION. Male. Total length: 6.0-6.7. Carapace: $2.9-3.27$ long, 2.25-2.42 wide. Carapace brownblack with lighter brown median band and black area near the eye field. Lateral bands brownish, more or less broken to form 3 distinct spots separated by narrow black stripes (Fig. 2). Sometimes stripes reduced or absent and lateral bands unbroken. Clypeus light brown, lighter than the rest of the cephalic area. Chelicerae brown with darker tip. Sternum black. Abdomen dark with brown cardiac mark bordered by black, flanked by two small lighter marks and with four pairs of spots extending beyond it and fused near the spinnerets. The whole pattern is usually faint. Legs yellowish without annulations, femur dark except for the distal part (Fig. 40). Leg I with long lateral hairs on metatarsus and tarsus, easily visible from above (Figs 49, 53, 55, 103). Leg I length: $2.65+1.22+2.2+2.45+1.52$. Leg I spination: femur d $3 \mathrm{p} 2 \mathrm{r} 2$, patella p1 r1, tibia p $2 \mathrm{r} 2 \mathrm{v} 2-$ 2, metatarsus p2(1) r2(1) v2-2. Palp as in Figs 20, 31, $66,72,78,84$; dark brown with lighter patella and tip of the cymbium.

Female. Total length: 7.6. Carapace: 3.22 long, 2.45 wide. Carapace brown with a yellowish median band and a darker area in the cephalic region. Continuous yellowish lateral bands with 3-4 small brown spots near the carapace margin (Fig. 12). Clypeus and chelicerae same colour as the lateral bands, chelicerae with faint darker marks. Sternum brown with darker marks in the middle. Abdomen dorsally dark brown with a brown-reddish cardiac mark. Five spots of the same colour surround and extend beyond the mark and are fused near the spinnerets. Ventral side yellowish with two lighter longitudinal stripes. Legs brownish with dark annulations.

Leg I length: $2.7+1.2+2.17+2.17+1.52$. Leg I spination: femur d3 p3 r2, patella p1 r0, tibia p2 r2 v2- 


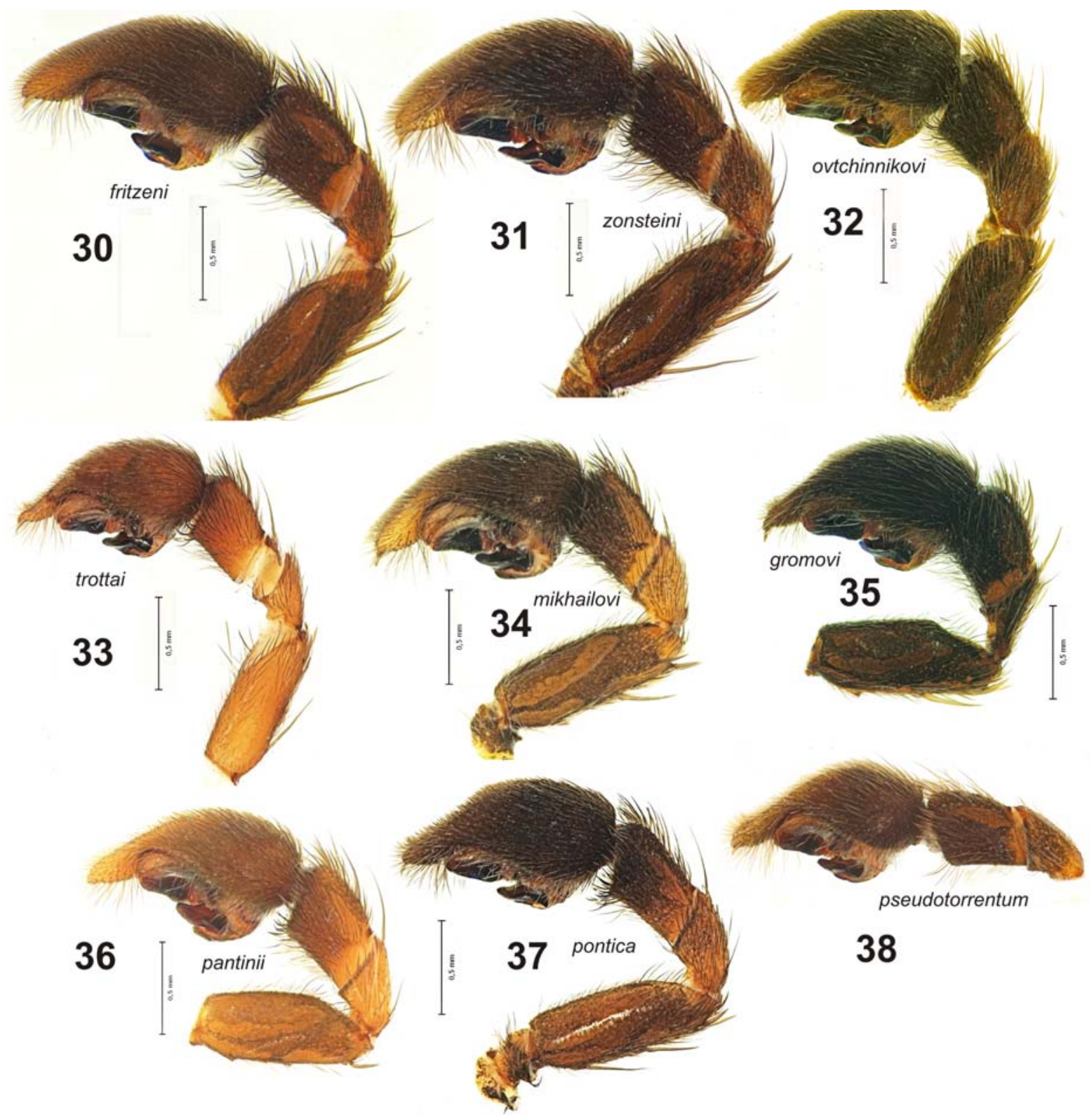

Figs 30-38. Retrolateral view of male palp of Pardosa fritzeni sp.n. (30), P. zonsteini sp.n. (31), P. ovtchinnikovi sp.n. (32), P. trottai sp.n. (33), P. mikhailovi sp.n. (34), P. gromovi sp.n. (35), P. pantinii sp.n. (36), P. pontica (37) and P. pseudotorrentum (38).

Рис. 30-38. Пальпы самца (ретролатерально) Pardosa fritzeni sp.n. (30), P. zonsteini sp.n. (31), P. ovtchinnikovi sp.n. (32), P. trottai sp.n. (33), P. mikhailovi sp.n. (34), P. gromovi sp.n. (35), P. pantinii sp.n. (36), P. pontica (37) и P. pseudotorrentum (38).

2, metatarsus p2 r0 v2-2. Epigyne and vulva as in Figs $108,117$.

DISTRIBUTION. Pardosa zonsteini sp.n. is widespread in Middle Asia (Fig. 126), and known from the northern border between Kyrgyzstan and Kazakhstan to the eastern part of Uzbekistan. It had previously been reported from south-eastern Uzbekistan by Charitonov [1969: sub. P. mixta].

Pardosa ovtchinnikovi sp.n. Figs 3, 13, 21, 32, 41, 56, 69, 75, 81, 87, 109, 118, 125.

TYPE MATERIAL. Holotype $\sigma^{7}$ and paratype $4 \sigma^{7} \sigma^{7} 5$ 우 (SZMN: SZM 001.3723) Tajikistan, Gorno-Badakhshan Area, near
Garavuti, $37^{\circ} 33^{\prime} \mathrm{N} 68^{\circ} 27^{\prime} \mathrm{E}, 22.4 .1986$ (A.A. Zyuzin); Paratypes: Tajikistan, $11 \sigma^{\top} \sigma^{\top} 1$ ( 9 (SZMN: SZM 001.3724) Ziddy Distr., Hissar Mountain Range $\left(38^{\circ} 33^{\prime} \mathrm{N} 68^{\circ} 33^{\prime} \mathrm{E}\right)$ 18.6.1988 (S.K. Alekseev); 3 ○ $^{\top} 2$ 우 (SZMN: SZM 001.4266) Kurgan-Tyube Region, Yavanski Distr., Chilisai gorge, 18.04 .1986 (A.A.Zyuzin); Turkmenistan, $1 \sigma^{\top} 1$ ( SE of Pulikkhatum Village, 14.04.1993 (S.V. Ovtchinnikov); Uzbekistan, $1 \bigcirc^{7} 1$ (ZMMU), Babatagh Mountain Range, Kafirnighan River Valley, 25.04.1994 (S.V. Ovtchinnikov).

ETYMOLOGY. The name of this species is a patronym in honour of the late Sergei V. Ovtchinnikov who made important contributions to studies of Middle Asian spiders. 


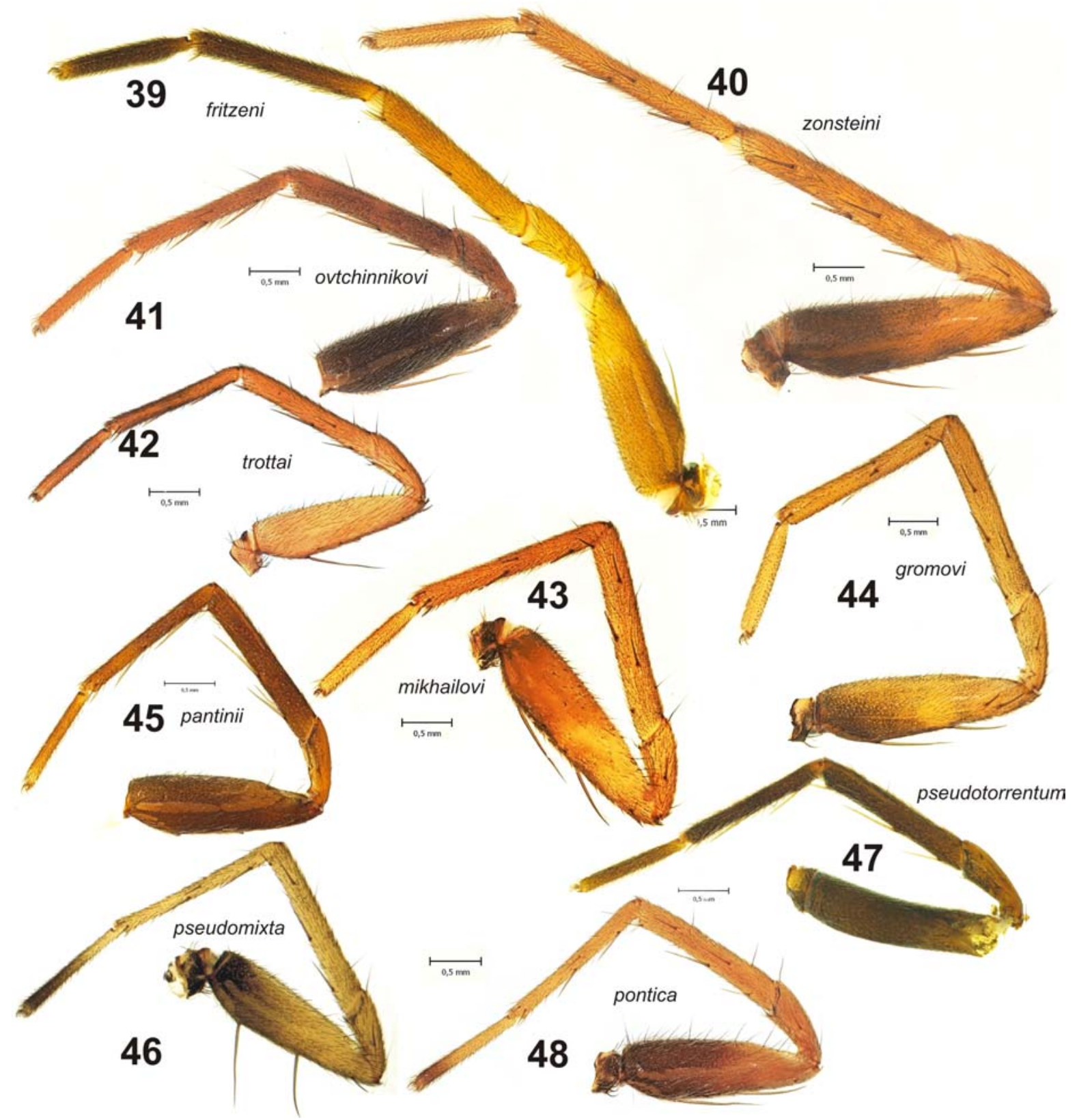

Figs 39-48. Retrolateral view of leg I in males of Pardosa fritzeni sp.n. (39), P. zonsteini sp.n. (40), P. ovtchinnikovi sp.n. (41), $P$. trottai sp.n. (42), P. mikhailovi sp.n. (43), P. gromovi sp.n. (44), P. pantinii sp.n. (45), P. pseudomixta (46), P. pseudotorrentum (47) and $P$. pontica (48): 46 — after Marusik \& Fritzén [2009], not to scale.

Рис. 39-48. Ноги І самцов (сзади) Pardosa fritzeni sp.n. (39), P. zonsteini sp.n. (40), P. ovtchinnikovi sp.n. (41), P. trottai sp.n. (42), P. mikhailovi sp.n. (43), P. gromovi sp.n. (44), P. pantinii sp.n. (45), P. pseudomixta (46), P. pseudotorrentum (47) и P. pontica (48): 46 — по Marusik \& Fritzén [2009], не в масштабе.

DIAGNOSIS. Pardosa ovtchinnikovi sp.n. is very similar to $P$. pseudotorrentum in terms of habitus and leg coloration, but the two species can be easily distinguished by the shape of the terminal apophysis, which is thin and narrow in P. ovtchinnikovi sp.n. and stumpy and triangular in P. pseudotorrentum (cf. Figs 28 and $69,81)$.

The new species can be separated from all the other Middle Asian species, including $P$. pseudomixta and $P$. pontica, by the darker coloration of its body and legs. P. ovtchinnikovi sp.n. females are indistinguishable from females of the other Middle Asian monticolagroup species.

DESCRIPTION. Male. Total length: 5.45-5.8. Carapace: $2.85-3.0$ long, 2.22-2.23 wide. Carapace very dark brown, almost black. Brownish narrow central stripe, lateral bands with the same colour broken to form three spots separated by thin black stripes (Fig. 

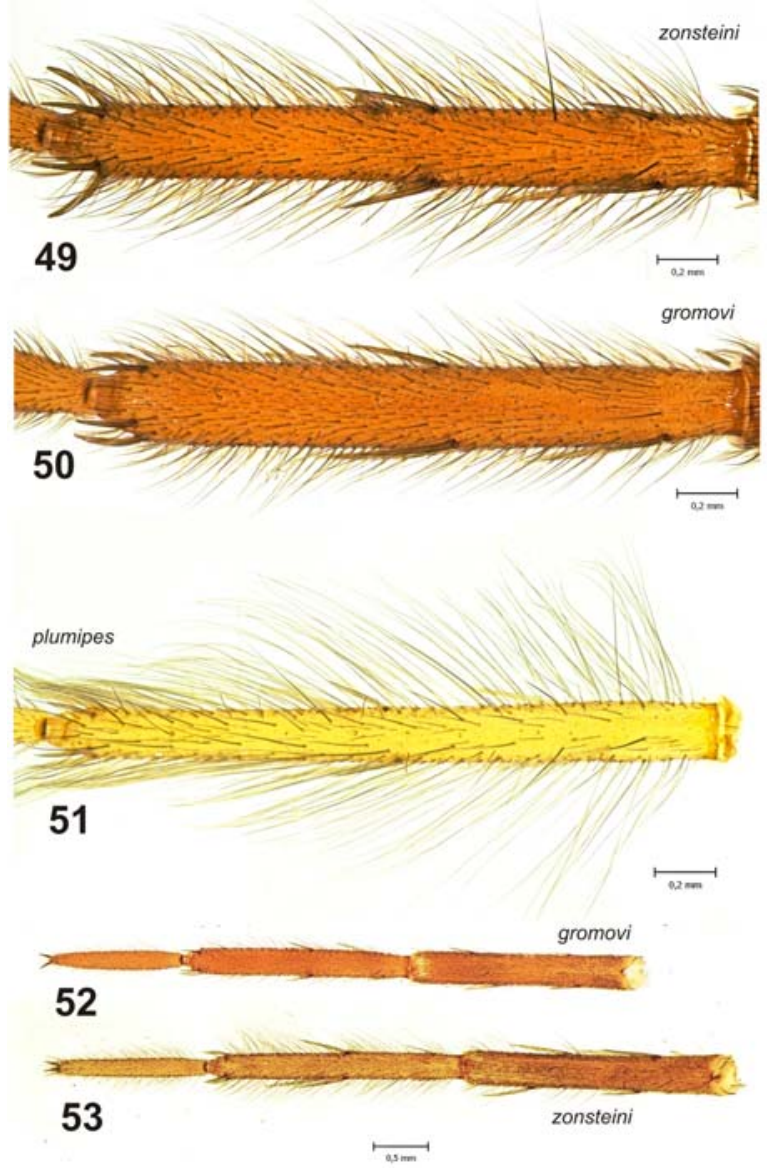

Figs 49-53. Dorsal view of leg I in male of Pardosa zonsteini sp.n. $(49,53)$, P. gromovi sp.n. $(50,52)$ and P. plumipes $(51)$.

Рис. 49-53. Ноги I самцов (сверху) Pardosa zonsteini sp.n. (49, 53), P. gromovi sp.n. $(50,52)$ и P. plumipes $(51)$.

3). Clypeus brown, lighter than cephalic flanks. Chelicerae almost uniform dark brown with yellowish internal (mesal) surface. Sternum black. Abdomen as dark as the carapace, with a lighter but faint cardiac mark, ventral surface same colour as dorsally. Leg I with femur almost black, patella and tibia dark brown with faint marks, tarsus and metatarsus lighter (Fig. 41, 56). Leg I length: $2.0+0.9+1.72+1.75+1.17$. Leg I spination: femur d $3 \mathrm{p} 2 \mathrm{r} 2$, patella $\mathrm{p} 1 \mathrm{r} 1$, tibia $\mathrm{p} 2 \mathrm{r} 2 \mathrm{v} 2-$ 2, metatarsus 1 r1 v2-2.

Palp as in Figs 21, 32, 69, 75, 81, 87; uniformly brownish.

Female. Total length: 7.1-7.85. Carapace: 3.153.17 long, 2.42-2.45 wide.

Carapace brown with a yellow central band and blackish ocular area. Lateral bands yellow and more or less divided into three spots by two narrow, sometimes broken, brown stripes (Fig. 13). Clypeus and chelicerae yellowish, sternum dark brown, a little lighter in the middle and around the lateral edges.

Abdomen dorsally dark brown with brown-reddish cardiac mark surrounded and followed by pairs of spots of the same colour. Spots are fused near the spinnerets. Abdomen ventrally yellow-brownish with two yellow longitudinal stripes. Legs brownish with darker annulations and darker marks. Leg I length: $2.22+1.1+1.87+$ $1.87+1.22$. Leg I spination: femur d3 p2 r2, patella p1 r0, tibia p2 r2 v2-2, metatarsus p1 r1 v2-2. Epigyne and vulva as in Figs 109, 118.

DISTRIBUTION. Pardosa ovtchinnikovi sp.n. seems to be distributed in the large plain areas from the southern part of Turkmenistan to south-eastern Uzbekistan and south-western Tajikistan (Fig. 126).

Pardosa trottai sp.n.

Figs 4, 18, 22, 33, 42, 57, 65, 71, 77, 83, 100, 110, $119,125$.

TYPE MATERIAL. Holotype $\sigma^{7}$ and paratype 1 (ZMMU) Kyrgyzstan, Terskey Mountain Range, Aksu River, near Teploklyuchenka Village (42²9'48'” 78³1'36'"E), 19.06.1993 (S.V. Ovtchinnikov).

ETYMOLOGY. The name of this species is a patronym in honour of our friend and colleague Alessio Trotta (Italy) who has made important contributions to arachnology.

DIAGNOSIS. Pardosa trottai sp.n. is closely related to $P$. pantinii sp.n. Males of the two species can be easily distinguished by the lack of white hairs on the palpal patella in $P$ trottai sp.n., besides this species does not have an abdominal pattern (cf. Figs 4 and 7) and tarsus I is thicker than in the other legs, not thin as in $P$. pantinii sp.n. $P$. trottai sp.n. can be easily separated from all other Middle Asian Pardosa species of the monticola-group including P. pseudomixta

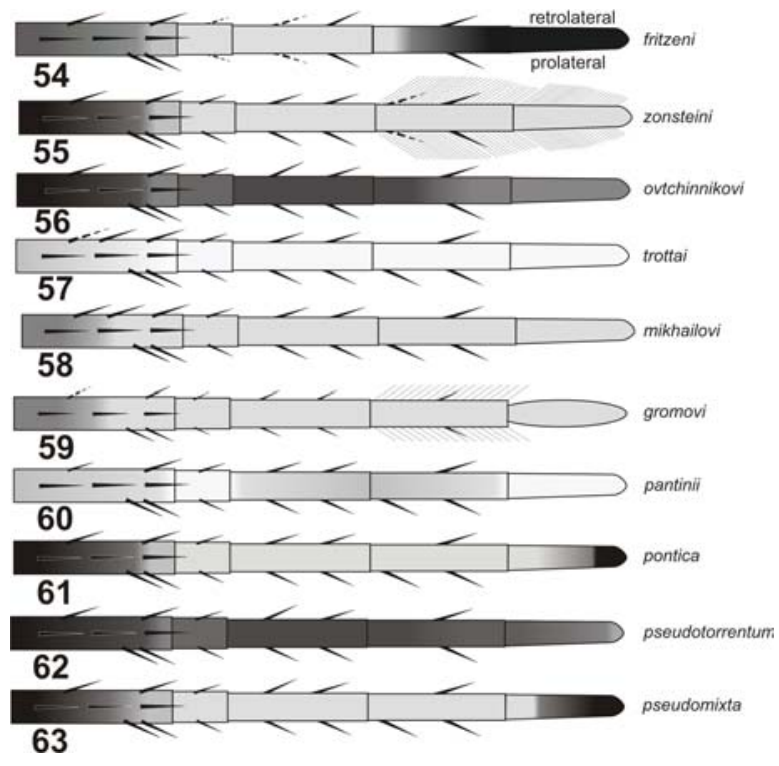

Figs 54-63. Scheme of spination and coloration of leg I in males of Pardosa fritzeni sp.n. (54), P. zonsteini sp.n. (55), P. ovtchinnikovi sp.n. (56), P. trottai sp.n. (57), P. mikhailovi sp.n. (58), P. gromovi sp.n. (59), P. pantinii sp.n. (60), P. pontica (61), $P$. pseudotorrentum (62) and $P$. pseudomixta (63).

Рис. 54-63. Схема шипования и окраски ноги I у самцов Pardosa fritzeni sp.n. (54), P. zonsteini sp.n. (55), P. ovtchinnikovi sp.n. (56), P. trottai sp.n. (57), P. mikhailovi sp.n. (58), P. gromovi sp.n. (59), $P$. pantinii sp.n. (60), $P$. pontica (61), $P$. pseudotorrentum (62) и $P$. pseudomixta (63). 

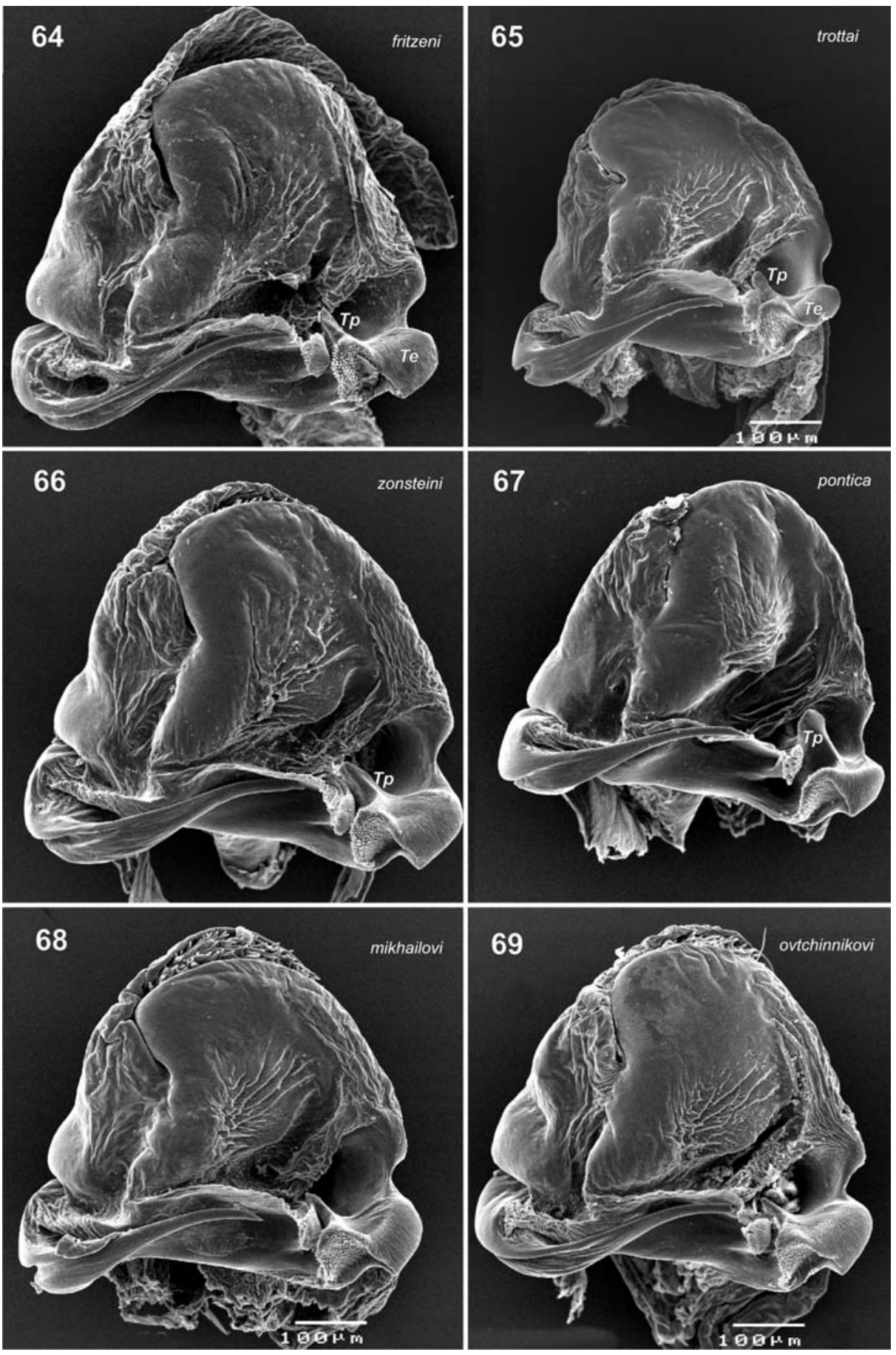

Figs 64-69. Ventral view of embolic division of Pardosa fritzeni sp.n. (64), P. trottai sp.n. (65), P. zonsteini sp.n. (66), P. pontica (67), P. mikhailovi sp.n. (68) and P. ovtchinnikovi sp.n. (69).

Рис. 64-69. Эмболюсный отдел, вид снизу, у Pardosa fritzeni sp.n. (64), P. trottai sp.n. (65), P. zonsteini sp.n. (66), P. pontica (67), P. mikhailovi sp.n. (68) и P. ovtchinnikovi sp.n. (69).

and $P$. pseudotorrentum by the brown-reddish coloration, very unusual for this species-group, the lack of an abdominal pattern, its small size and the yellow sternum and legs.

Females differ from other species, except $P$. pantinii sp.n., by their smaller size and the yellowish colora- tion of sternum, legs and abdomen markings. They can be separated from $P$. pantinii sp.n. females by the different abdominal pattern being less yellowish, and by the different shape of the vulval receptacles, which are bent inwards in P. trottai sp.n. and more straight in P. pantinii sp.n. (cf. Figs 119 and 121). 

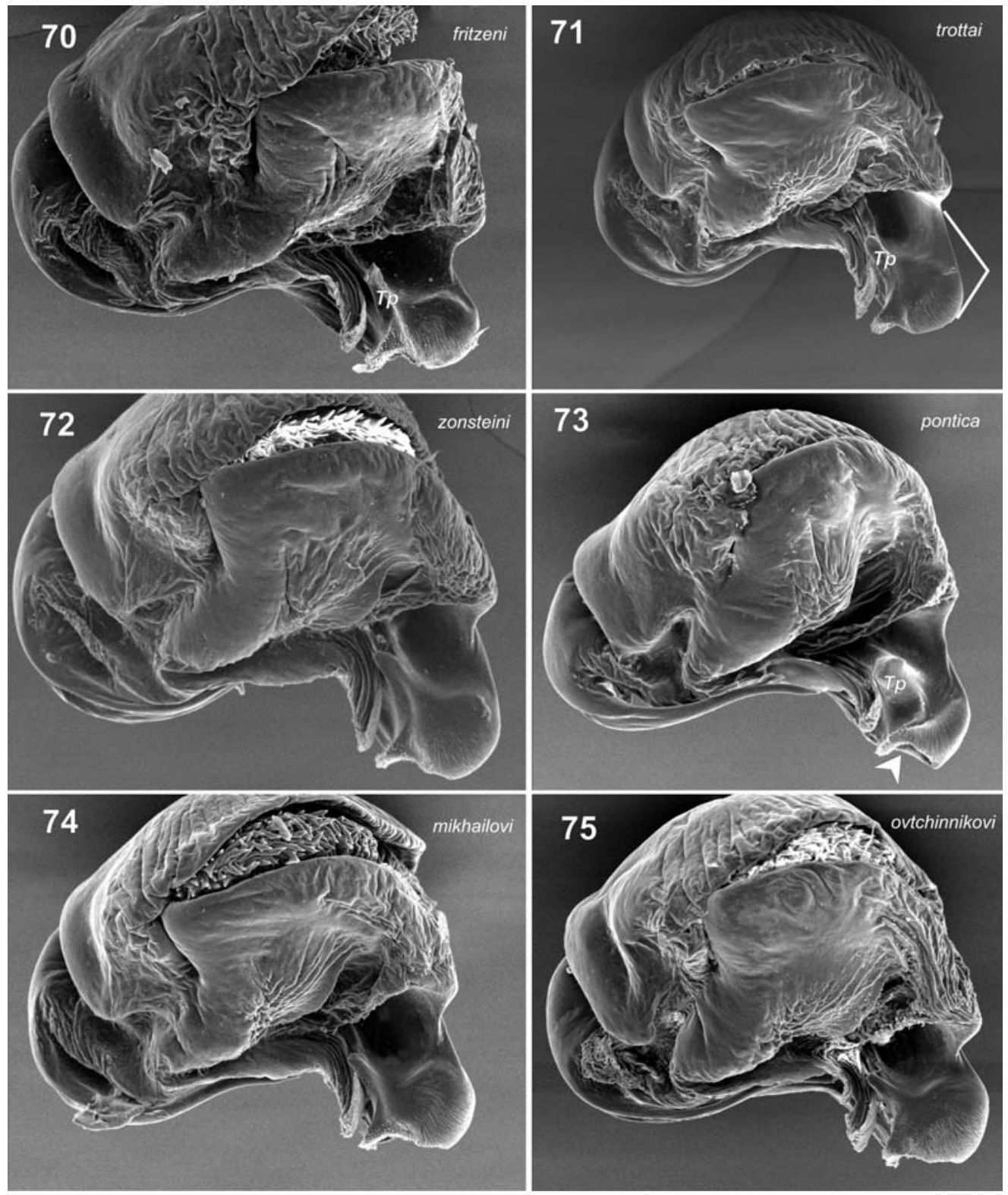

Figs 70-75. Anterior view of embolic division of Pardosa fritzeni sp.n. (70), P. trottai sp.n. (71), P. zonsteini sp.n. (72), P. pontica (73), P. mikhailovi sp.n. (74) and P. ovtchinnikovi sp.n. (75).

Рис. 70-75. Эмболюсный отдел (вид спереди) Pardosa fritzeni sp.n. (70), P. trottai sp.n. (71), P. zonsteini sp.n. (72), P. pontica (73), P. mikhailovi sp.n. (74) и P. ovtchinnikovi sp.n. (75).

DESCRIPTION. Male. Total length: 4.65. Carapace: 2.45 long, 1.18 wide. Carapace brown-reddish with black area near the eye field and slightly darker radiating stripes in the middle (Fig. 4). Lighter unbroken lateral bands, indistinct. Clypeus and chelicerae brown-reddish as are the cephalic flanks. Sternum yellow-brownish. Abdomen of uniform colour and lacking a distinct pattern. Legs yellowish without annulations or other markings (Figs 42, 57). Leg I with tarsus thicker than in the other legs. Leg I length: $1.74+0.85+$ $1.47+1.44+1.0$. Leg I spination: femur d3 p2 r3(2), patella p1 r1, tibia p2 r2 v2-2, metatarsus p2 r1 v2-2.
Palp as in Figs 22, 33, 65, 71, 77, 83; brownreddish with femur and patella lighter than tibia and cymbium.

Female. Total length: 6.05. Carapace: 3.02 long, 2.22 wide. Carapace brownish with black eye field and yellow median band dilated in cephalic area, wide unbroken yellow lateral bands with 2-3 small darker spots near the carapace edge (Fig. 18). Sternum yellow with small dark spots in the submedian area and near the edge. Chelicerae yellow.

Abdomen dark brown, almost black, with distinct yellow cardiac mark flanked and followed by 6 pairs of 

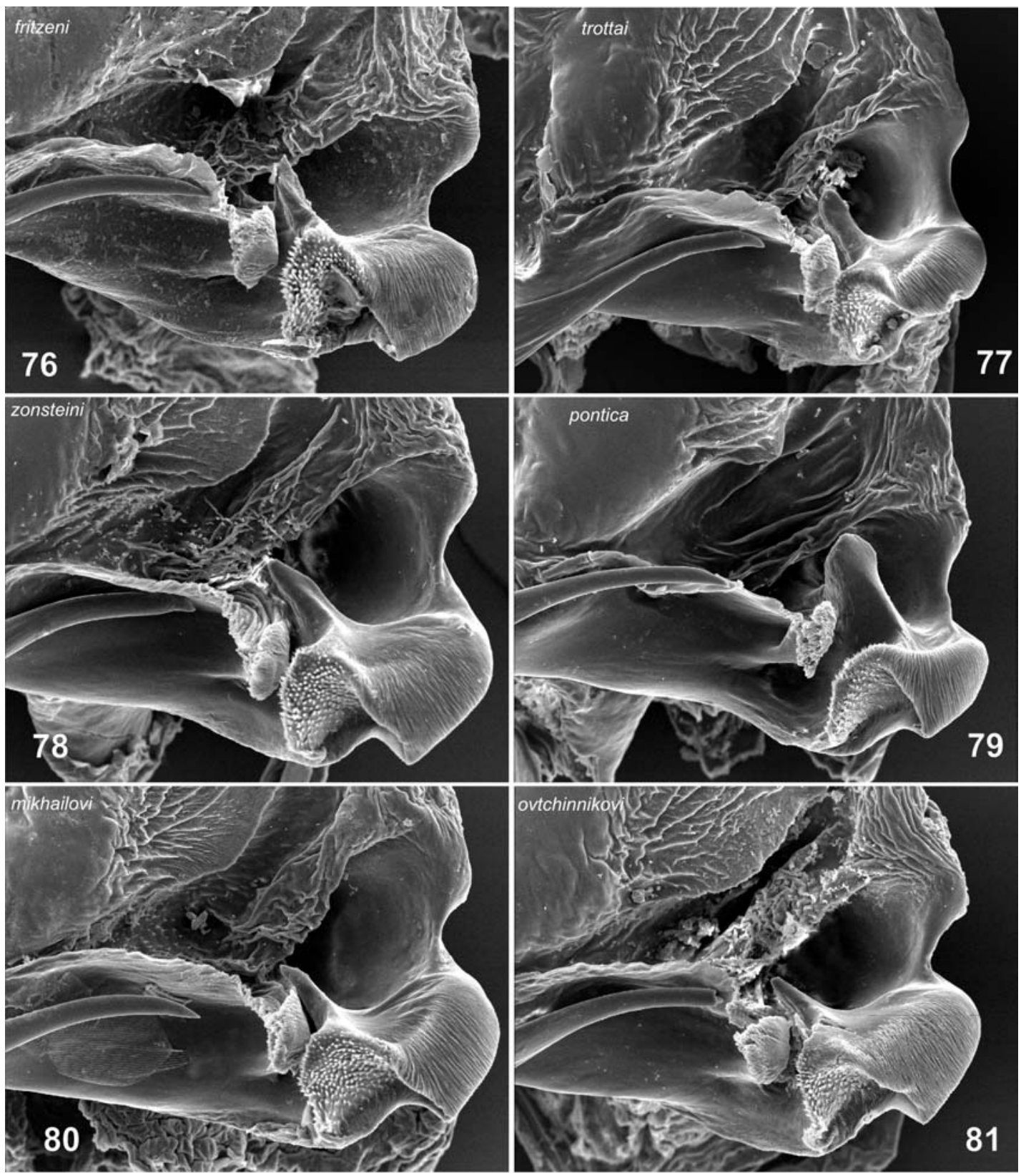

Figs 76-81. Terminal part of embolic division of Pardosa fritzeni sp.n. (76), P. trottai sp.n. (77), P. zonsteini sp.n. (78), P. pontica (79), P. mikhailovi sp.n. (80) and P. ovtchinnikovi sp.n. (81). Ventral view.

Рис. 76-81. Терминальная часть эмболюсного отдела (вид снизу) у Pardosa fritzeni sp.n. (76), P. trottai sp.n. (77), P. zonsteini sp.n. (78), P. pontica (79), P. mikhailovi sp.n. (80) и P. ovtchinnikovi sp.n. (81).

spots of the same colour, which are fused near the spinnerets. Ventral side of abdomen pale yellow with two lighter longitudinal stripes in the centre. Legs yellow, femur with faint dorsal darker marks. Leg I length: $2.4+1.12+1.95+1.97+1.34$. Leg I spination: femur d3 p2 r2, patella p1 r0, tibia p2 r2 v2-2, metatarsus p2 r1 v2-2. Epigyne and vulva as in Figs $110,119$.

DISTRIBUTION. $P$. trottai sp.n. is known from the type locality only, the area near the village of Teploklyuchenka in Terskey Mountain Range, Kyr- gyzstan (Fig. 126). This species occurs in the same area as $P$. fritzeni sp.n.

\section{Pardosa mikhailovi sp.n.}

Figs 5, 24, 34, 43, 58, 68, 74, 80, 86, 125.

TYPE MATERIAL. Holotype $O^{7}$ (ZMMU), Kazakhstan, Almaty Area, Sarkha District, approximately $18 \mathrm{~km}$ south-east of Kokterek village, right bank of Lepsy River, $460 \mathrm{~m}, 46^{\circ} 4^{\prime} 56.07^{\prime \prime} \mathrm{N}$ $79^{\circ} 35^{\prime} 10.17^{\prime \prime} \mathrm{E}, 12.06 .2001$ (A.V. Gromov).

ETYMOLOGY. The specific name is a patronym in honour of our friend and colleague Kirill G. 

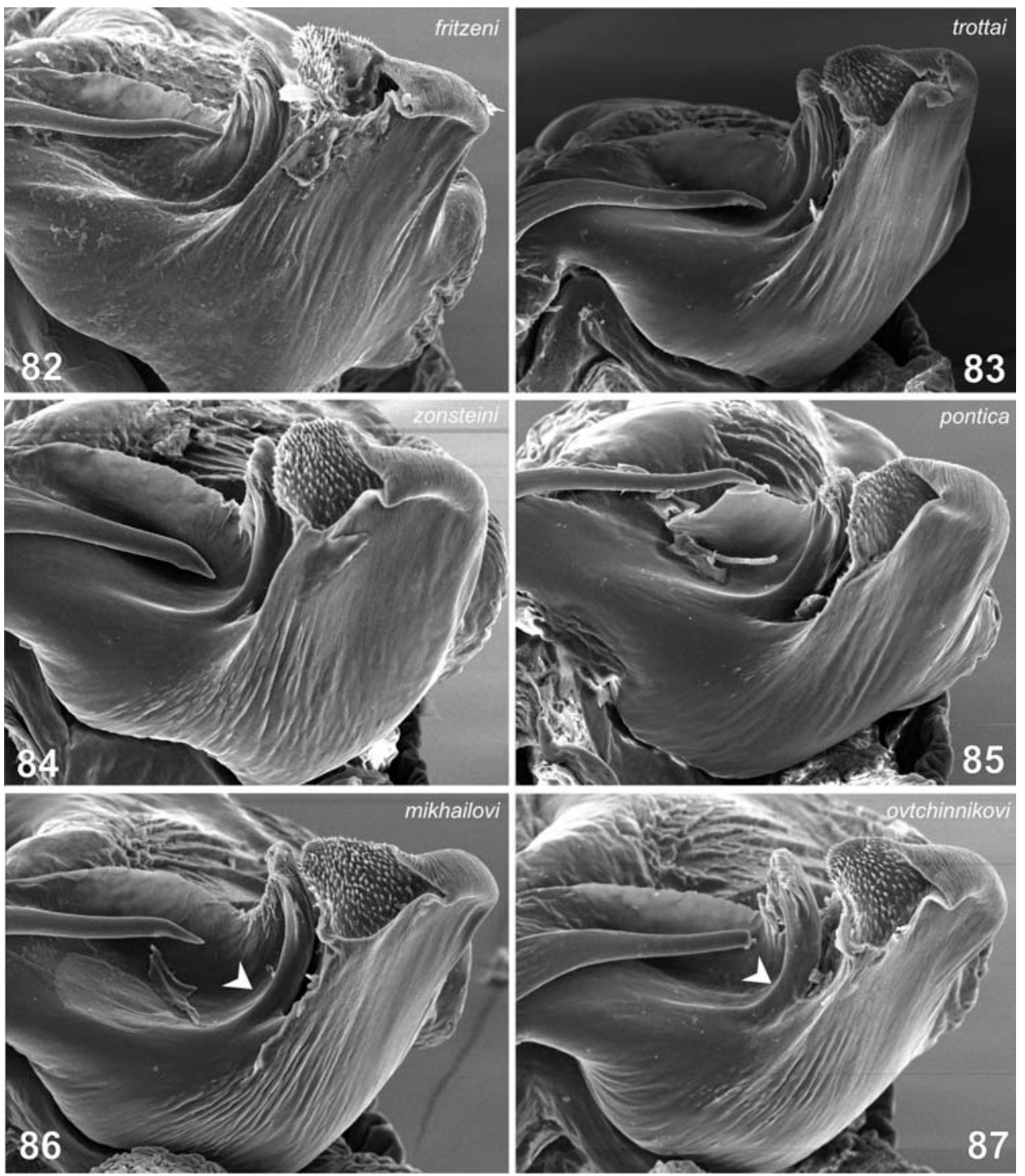

Figs 82-87. Posterior view of embolic division of Pardosa fritzeni sp.n. (82), P. trottai sp.n. (83), P. zonsteini sp.n. (84), P. pontica (85), P. mikhailovi sp.n. (86) and P. ovtchinnikovi sp.n. (87).

Рис. 82-87. Эмболюсный отдел (вид сзади) Pardosa fritzeni sp.n. (82), P. trottai sp.n. (83), P. zonsteini sp.n. (84), P. pontica (85), P. mikhailovi sp.n. (86) и P. ovtchinnikovi sp.n. (87).

Mikhailov (Russia) who has made important contributions to arachnology.

DIAGNOSIS. Males of P. mikhailovi sp.n. can be recognized by the yellow coloration of palpal patella, which are darker in all other Middle Asian species except $P$. pontica. It can be separated easily from this species by the different shape of the terminal apophysis, which is slimmer than in $P$. pontica (cf. Figs 67 and 68,79 and 80), and by the absence of the dark tip of tarsus I (cf. Figs 43 and 48, 58 and 61). The different leg I coloration also readily distinguishes $P$. mikhailovi sp.n. from $P$. pseudotorrentum and $P$. pseudomixta (cf. Figs 43 and 47-48, 58 and 62-63).

DESCRIPTION. Male. Total length: 5.55. Carapace: 2.8 long, 2.22 wide. Carapace brown, almost black around the eye field, median band brown-yellow- ish, lateral bands unbroken, same colour as median band (Fig. 5). Clypeus yellowish, lighter than surrounding area. Chelicerae dark brown with lighter longitudinal stripes and internal margin. Sternum black. Abdomen dorsally dark brown with clear visible lighter cardiac mark and six pairs of brownish spots around it and behind, spots fused near the spinnerets. Ventral side of abdomen lighter than dorsal side. Legs uniform yellow-brownish with some small darker areas on the femur, especially dorsally (Figs 43, 58). Leg I with tarsus thicker than in the other legs. Leg I length: $2.27+1.1+1.9+2.05+1.25$. Leg I spination: femur d3 p2 r3, patella p1 r1, tibia p2 r2 v2-2, metatarsus p2 r1 v2-2.

Palp as in Figs 24, 34, 68, 74, 80, 86; brown with tip of the cymbium and patella yellow. 

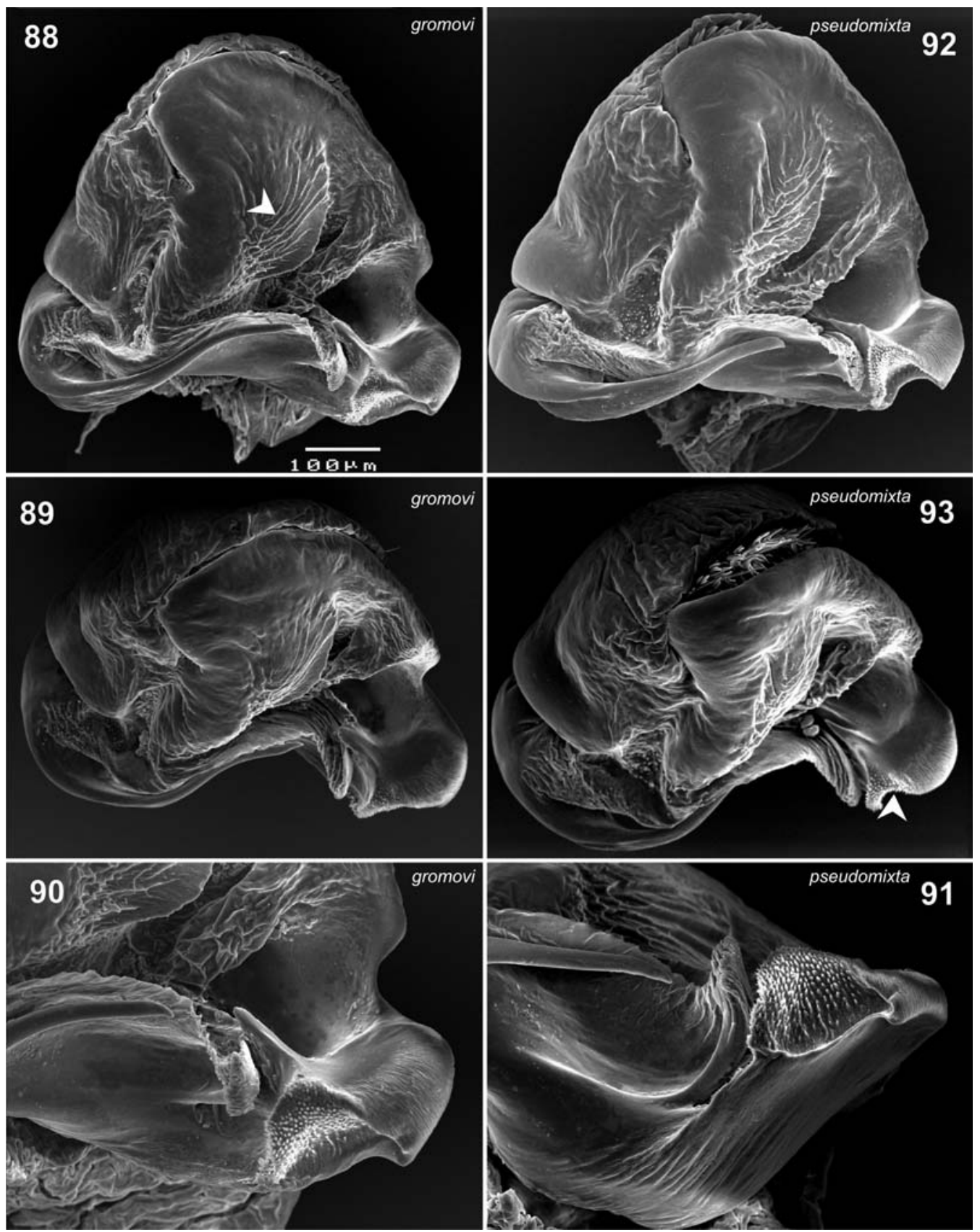

Figs 88-93. Embolic division of Pardosa gromovi sp.n. (88-91) and P. pseudomixta (92-93): 88, 92 — ventral; 89, 93 — anterior; 90 - terminal part, ventral; 91 - terminal part, posterior.

Рис. 88-93. Эмболюсный отдел Pardosa gromovi sp.n. (88-91) и P. pseudomixta (92-93): 88, 92 — вентрально; 89, 93 спереди; 90 - терминальная часть, вентрально; 91 - терминальная часть, сзади.

DISTRIBUTION. This species is known from the type locality only, an unspecified area south-east of Kokterek village near the Lepsy River in the Sarkha District, Kazakhstan (Fig. 126).

Pardosa gromovi sp.n.

Figs 6, 15, 23, 35, 44, 50, 52, 59, 88-91, 101, 105, $111,120,125$.

TYPE MATERIAL. Holotype $\sigma^{7}$ and paratypes $20^{7} \sigma^{7} 5$ (ZMMU), Kazakhstan, Almaty Area, Aksu District, ca. $2.5 \mathrm{~km}$ south-east of Matai, left bank of Aksu River, $45^{\circ} 53^{\prime} \mathrm{N} 78^{\circ} 45^{\prime} \mathrm{E}$, 29.06.2001 (A.V. Gromov); $6 \mathrm{O}^{7} \mathrm{O}^{7}$ (ZMMU), environs of Almaty, Bol'shoye Almaatinskoye Lake, $43^{\circ} 05^{\prime} \mathrm{N} 76^{\circ} 59^{\prime} \mathrm{E}, 2500 \mathrm{~m}, 3-10$. 07.1995 (O.A. Karacheva); $30^{7} 0^{7}$ (AGPC) Zhambyl Area, 42 $40^{\prime}$ $00.1^{\prime \prime} \mathrm{N} 70^{\circ} 48^{\prime} 08.4^{\prime \prime} \mathrm{E}, 966 \mathrm{~m}, 23.06 .2011$ (A.V. Gromov), $10^{7}$ (AGPC) South Kazakhstan Area, Karatan Mountain Range, Koshkarath river, river valley, $750 \mathrm{~m}, 42^{\circ} 53^{\prime} 42.5^{\prime \prime} \mathrm{N} 70^{\circ} 10^{\prime} 14.4^{\prime \prime} \mathrm{E}, 20.06$. 2011 (I.I. Temreshev); $4 \mathrm{O}^{7} \mathrm{O}^{7} 7$ 우 (AGPC401) Almaty Area, 794 $\mathrm{m}, 43^{\circ} 17^{\prime} 45.5^{\prime \prime} \mathrm{N} 76^{\circ} 06^{\prime} 45.1^{\prime \prime E}, 24.06 .2011$ (A.V. Gromov); $20^{7} \sigma^{7}$ 2 우 (ZMMU) $498 \mathrm{~m}, 43^{\circ} 57^{\prime} 58.5^{\prime \prime} \mathrm{N} 79^{\circ} 28^{\prime} 19.8^{\prime \prime} \mathrm{E}, 3.05 .2010$, saline soil and meadow (A.V. Gromov); $20^{7} 0^{7} 1$ ㅇ (MSNV) Almaty Area, $777 \mathrm{~m}, 43^{\circ} 16^{\circ} 02.8^{\prime \prime} \mathrm{N} 76^{\circ} 17^{\prime} 59.5^{\prime \prime} \mathrm{E}, 24.06 .2011$ (A.V. 


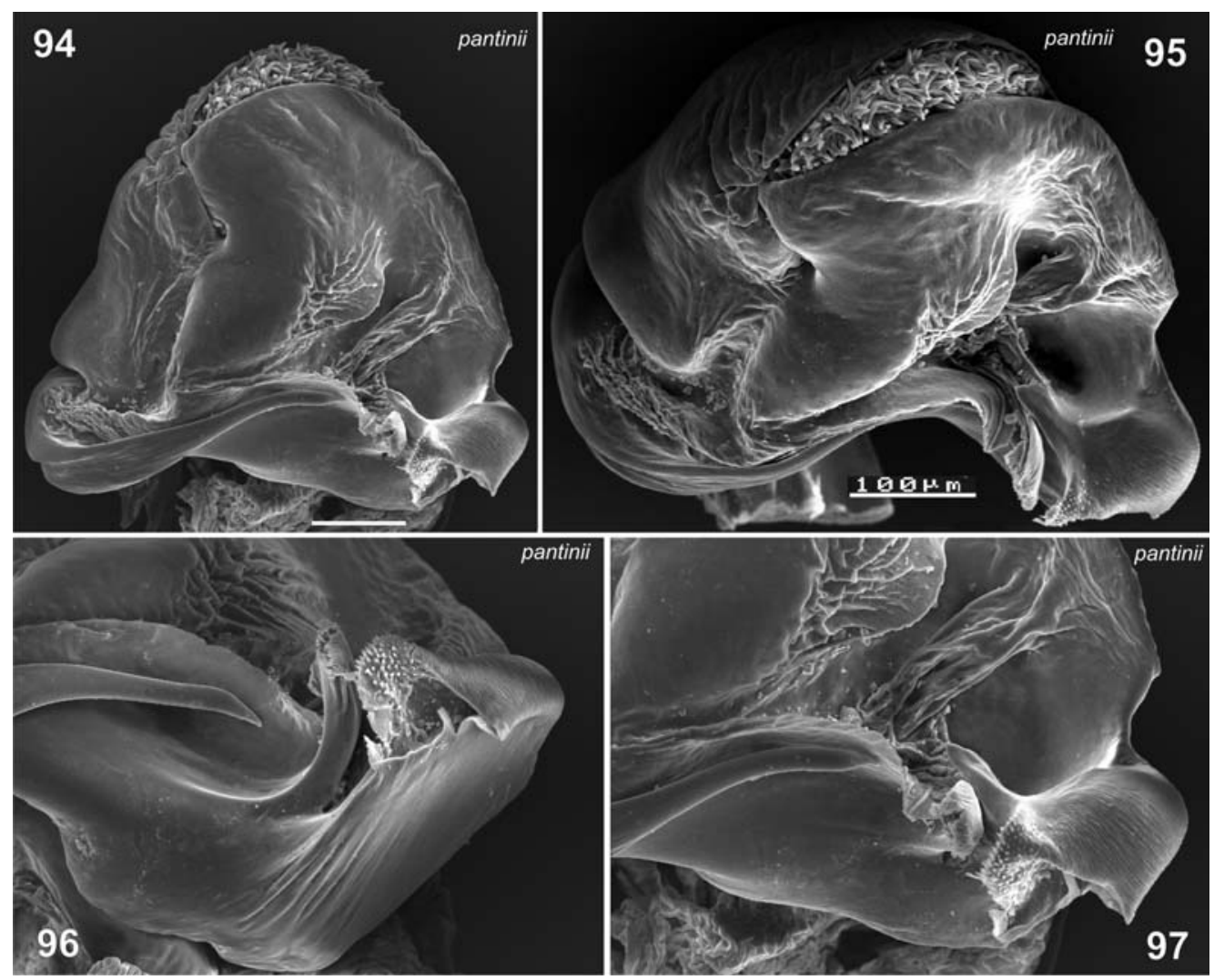

Figs 94-97. Embolic division of Pardosa pantinii sp.n.: 94 - ventral; 95 — anterior; 96 — terminal part, posterior; 97 — terminal part, ventral.

Рис. 94-97. Эмболюсный отдел Pardosa pantinii sp.n.: 94 - вентрально; 95 - спереди; 96 - терминальная часть, сзади; 97 терминальная часть, вентрально.

Gromov); $50^{7} \sigma^{7} 7$ + 9 (AGPC) Zhambyl Area, $1023 \mathrm{~m}, 42^{\circ} 43^{\prime}$ $38.0^{\prime \prime} \mathrm{N} 70^{\circ} 32^{\prime} 57.7^{\prime \prime} \mathrm{E}, 23.06 .2011$ (A.V. Gromov); 4 O’ $^{7} 7$ 우 (AGPC) Zhambyl Area, $911 \mathrm{~m}, 43^{\circ} 22^{\prime} 35.9^{\prime \prime} \mathrm{N} 75^{\circ} 02^{\prime} 57.5^{\prime \prime} \mathrm{E}, 24.06$ 2011 (A.V. Gromov).

ETYMOLOGY. The name is a patronym in honour of the collector of the holotype, our friend and colleague Alexander V. Gromov (Kazakhstan) who has made important contributions to studies of Middle Asian spiders.

DIAGNOSIS. Pardosa gromovi sp.n. is closely related to $P$. zonsteini sp.n. Males of the two species can be separated by the different shape of leg I, P. gromovi sp.n. has a shorter and swollen tarsus and shorter lateral hairs on metatarsus I, usually as long as the diameter of the leg (cf. Figs 49 and 50, 52 and 53). Leg I shape, with swollen tarsus and rather long lateral hairs on the metatarsus, also serves to distinguish this new species from the other Middle Asian monticola-group species, including $P$. pontica, P. pseudomixta and P. pseudomonticola.

P. gromovi sp.n. females can be separated from other group members by the shape of the epigyne septum, which is quite narrow in the middle and large basally (Fig. 111), and by the vulval receptacles, which bend outwards (Fig. 120).

DESCRIPTION. Male. Total length: 5.35-5.95. Carapace: 2.82-3.12 long, 2.1-2.32 wide. Carapace brown with darker, almost black, cephalic area and brownish median band; lateral bands broken, same colour as median band (Fig. 6). Clypeus yellowish, chelicerae dark brown with lighter longitudinal stripes, same colour as the internal (mesal) surface. Sternum dark brown with a lighter narrow stripe mid-anteriorly. Dorsal side of abdomen dark brown with lighter cardiac mark, surrounded and followed by small spots of the same colour, which are fused near the spinnerets. Ventral side of abdomen dark in the middle and lighter near the lateral edges. Legs brown-yellowish with darker marks on the dorsal aspect of the femur (Fig. 44). Leg I with the same colour, metatarsus I with rather long hairs more visible from above, tarsus I swollen, thicker than in the other legs (Figs 50, 52, 59, 101, 105). Leg I length: $2.2+0.97+1.94+2.04+1.18$. Leg I spination: femur d3 p2 r2(1), patella p1 r1, tibia p2 r2 v2-2, metatarsus p1 r1 v2-2. Palp as in Figs 23, 35, 88-91; dark brown with lighter patella and dorsal aspect of tibia.

Female. Total length: 5.95-7.6. Carapace: 3.1-4.0 long, 2.32-2.5 wide. Carapace brown with darker eye field and yellow central band. Lateral unbroken yellow bands with a brown stripe near the carapace margin broken to form several small spots (Fig. 15). Sometimes only a couple of spots are present. Clypeus yellow, chelicerae yellowish with brown tip. Abdomen 

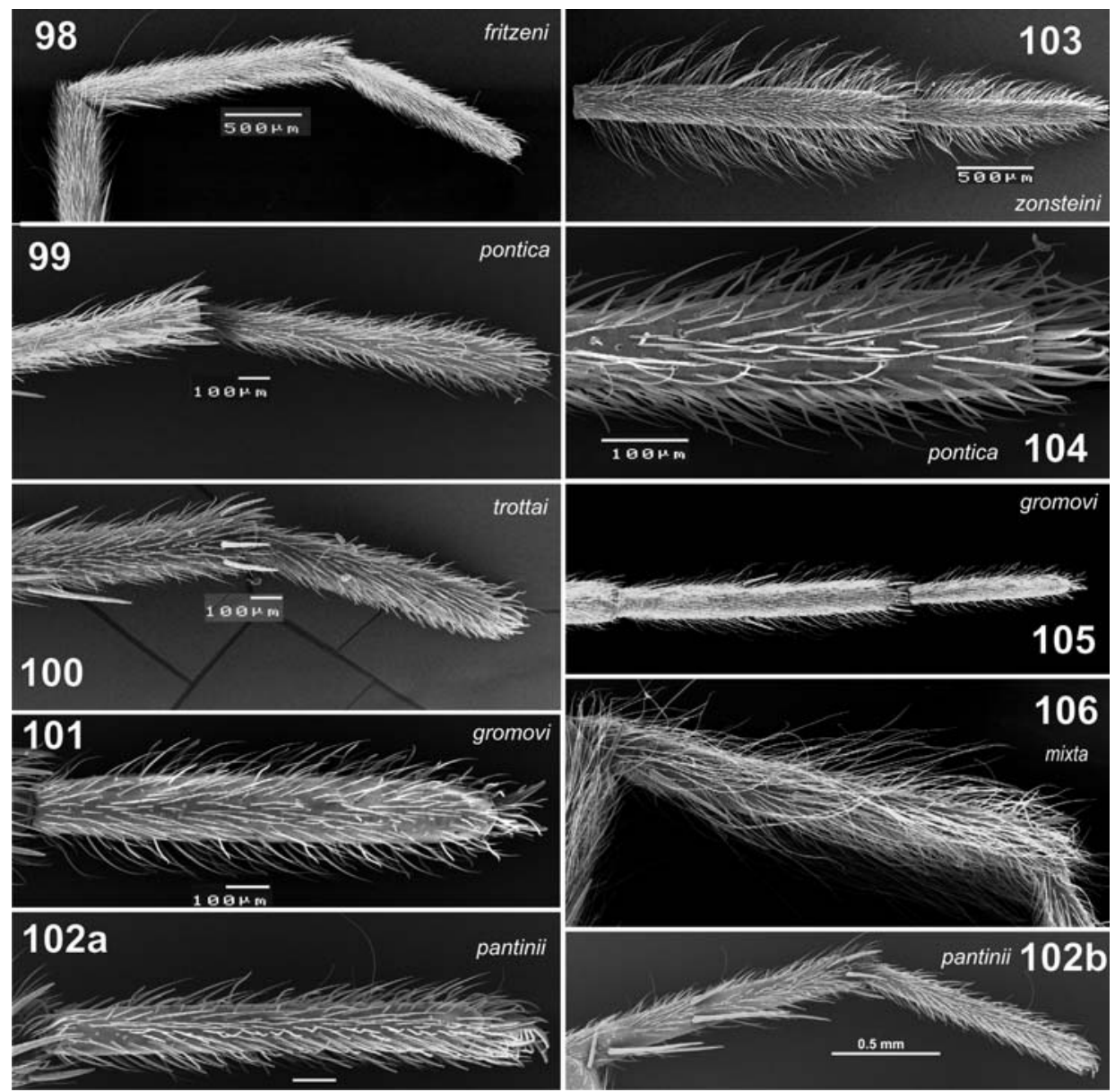

Figs 98-106. Leg I in males of Pardosa fritzeni sp.n. (98), P. pontica (99, 104), P. trottai sp.n. (100), P. gromovi sp.n. (101, 105), P. pantinii sp.n. (102), P. zonsteini sp.n. (103) and P. mixta (106): 98-100, 102, 106 - lateral; 101, 103-105 - dorsal. 106 - after Marusik \& Fritzén [2009].

Pис. 98-106. Нога I Pardosa fritzeni sp.n. (98), P. pontica (99, 104), P. trottai sp.n. (100), P. gromovi sp.n. (101, 105), P. pantinii sp.n. (102), P. zonsteini sp.n. (103) и P. mixta (106): 98-100, 102, 106 - латерально; 101, 103-105 — дорзально. 106 — по Marusik \& Fritzén [2009].

dorsally dark brown with a brown-reddish cardiac mark, 4-5 spots of the same colour, usually fused to each other, surround and extend beyond the mark. Ventral surface of the abdomen yellowish with two yellow longitudinal stripes.

Legs brownish with dark annulations. Leg I length: $2.47+1.15+2.08+2.05+1.38$. Leg I spination: femur d3 p2 r2, patella p1 r0, tibia p2 r2 v2-2, metatarsus p1(2) r1 v2-2. Epigyne and vulva as in Figs 111, 120.

DISTRIBUTION. Pardosa gromovi sp.n. has a wide distribution in the south-east of Kazakhstan near the border with Kyrgyzstan (Fig. 126).

Pardosa pantinii sp.n.

Figs 7, 11, 25, 36, 45, 60, 94-97, 102a,b, 112, 121, 125.

TYPE MATERIAL. Holotype $\sigma^{x}$ and paratypes $4 \sigma^{7} O^{7} 10$ 우 (SZMN: SZM 001.3721) Tajikistan, Dzhirgatal, $39^{\circ} 13^{\prime} \mathrm{N} 71^{\circ} 12^{\prime}$ E, $1800 \mathrm{~m}, 3.08 .1977$ (collector unknown).

ETYMOLOGY. This species is named after our friend and colleague Paolo Pantini (Italy) who has made important contributions to spider taxonomy.
DIAGNOSIS. Pardosa pantinii sp. n. is very similar to $P$. trottai sp.n. Males of $P$. pantinii sp.n. can be easily separated by the presence of white hairs on the palpal patella, absent in P. trottai sp.n. (cf. Figs 33 and 36 ), by the well developed abdominal pattern and by the shape of tarsus I, which is not thicker than the tarsi of the other legs, whereas it is in P. trottai sp.n. Pardosa pantinii sp.n. males differ from all other Middle Asian monticola-group species, including $P$. pontica, $P$. pseudomixta and P. pseudotorrentum, by the brownreddish coloration and the yellow abdominal pattern.

Females of this species can be easily recognized by the yellow-reddish habitus (Fig. 11) and their small size. The most similar species to $P$. pantinii sp.n. is $P$. trottai sp.n., from which females can be separated by their more yellowish abdominal pattern (cf. Figs 11 and 18), annulated legs and the different shape of the vulval receptacles, which are straight rather than being bent inwards (cf. Figs 119 and 121).

DESCRIPTION. Male. Total length: 5-5.3. Carapace: $2.42-2.67$ long, $1.82-2.05$ wide. Carapace brown- 

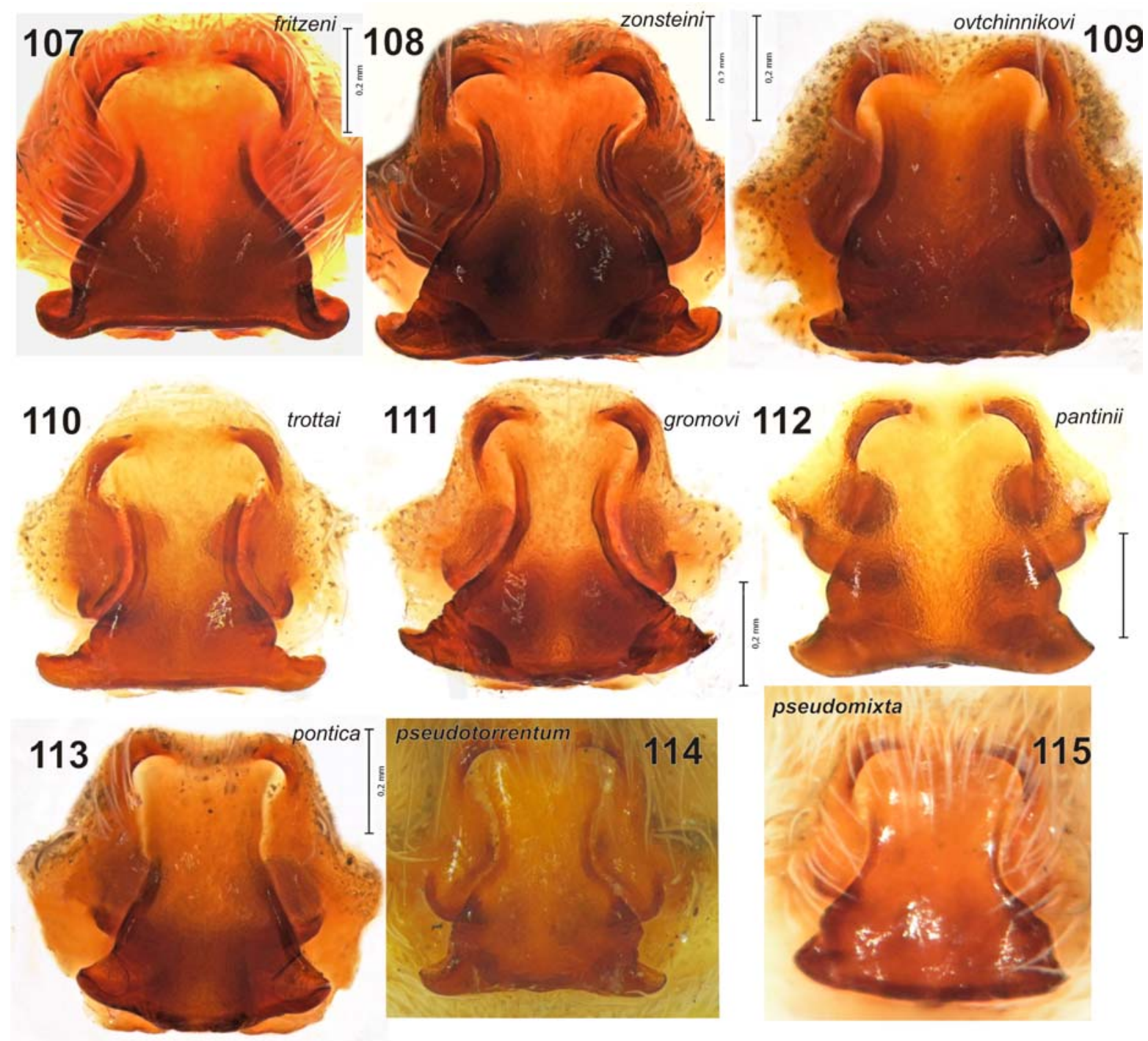

Figs 107-115. Ventral view of epigyne of Pardosa fritzeni sp.n. (107), P. zonsteini sp.n. (108), P. ovtchinnikovi sp.n. (109), P. trottai sp.n. (110), P. gromovi sp.n. (111), P. pantinii sp.n. (112), P. pontica (113), P. pseudotorrentum (114) and P. pseudomixta (115): $115-$ after Marusik \& Fritzén [2009], not to scale.

Рис. 107-115. Эпигина (вид снизу) Pardosa fritzeni sp.n. (107), P. zonsteini sp.n. (108), P. ovtchinnikovi sp.n. (109), P. trottai sp.n. (110), P. gromovi sp.n. (111), P. pantinii sp.n. (112), P. pontica (113), P. pseudotorrentum (114) и P. pseudomixta (115): 115 - по Marusik \& Fritzén [2009], не в масштабе.

reddish with a black area near the eyes and slightly darker radiating stripes in the middle. Lighter, faint central stripe broad in front. Lateral bands continuous and of the same colour (Fig. 7). Clypeus yellowish, chelicerae brown with lighter longitudinal stripes and yellowish internal margin. Sternum reddish-brown. Abdomen dark brown with a yellow cardiac mark surrounded and followed by marks of the same colour, the whole pattern is clearly visible. Ventral side of the abdomen yellow-brownish with two wide, yellow Vshaped stripes, which merge close to the spinnerets. Legs uniformly yellow-brownish with lighter patella and femur (Figs 45, 60). Leg I length: $1.98+0.92+$ $1.07+1.74+1.12$. Leg I spination: femur d3 p2 r2, patella p1 r1, tibia p2 r2 v2-2, metatarsus p2 r1 v2-2.
Palp as in Figs 25, 36, 94-97; uniformly brown, yellowish patella covered with white hairs.

Female. Total length: 5.2-6.6. Carapace: long 2.552.95, wide 1.92-2.32. Carapace brown-reddish with darker radiating stripes and black eye field. Yellowish central band and wide lateral unbroken stripes of the same colour, like the clypeus (Fig. 11). Chelicerae uniformly yellowish with brownish tip. Sternum yellow with a faint brownish U-shaped mark in the central area. Abdomen dorsally dark brown with a brown-reddish cardiac mark. It is surrounded and followed by yellow spots which are fused in the posterior region. Ventral side uniformly yellow with two wide lighter V-shaped stripes which merge close to the spinnerets. Legs yellow with brown annulations except on the lateral and ventral surfaces of 

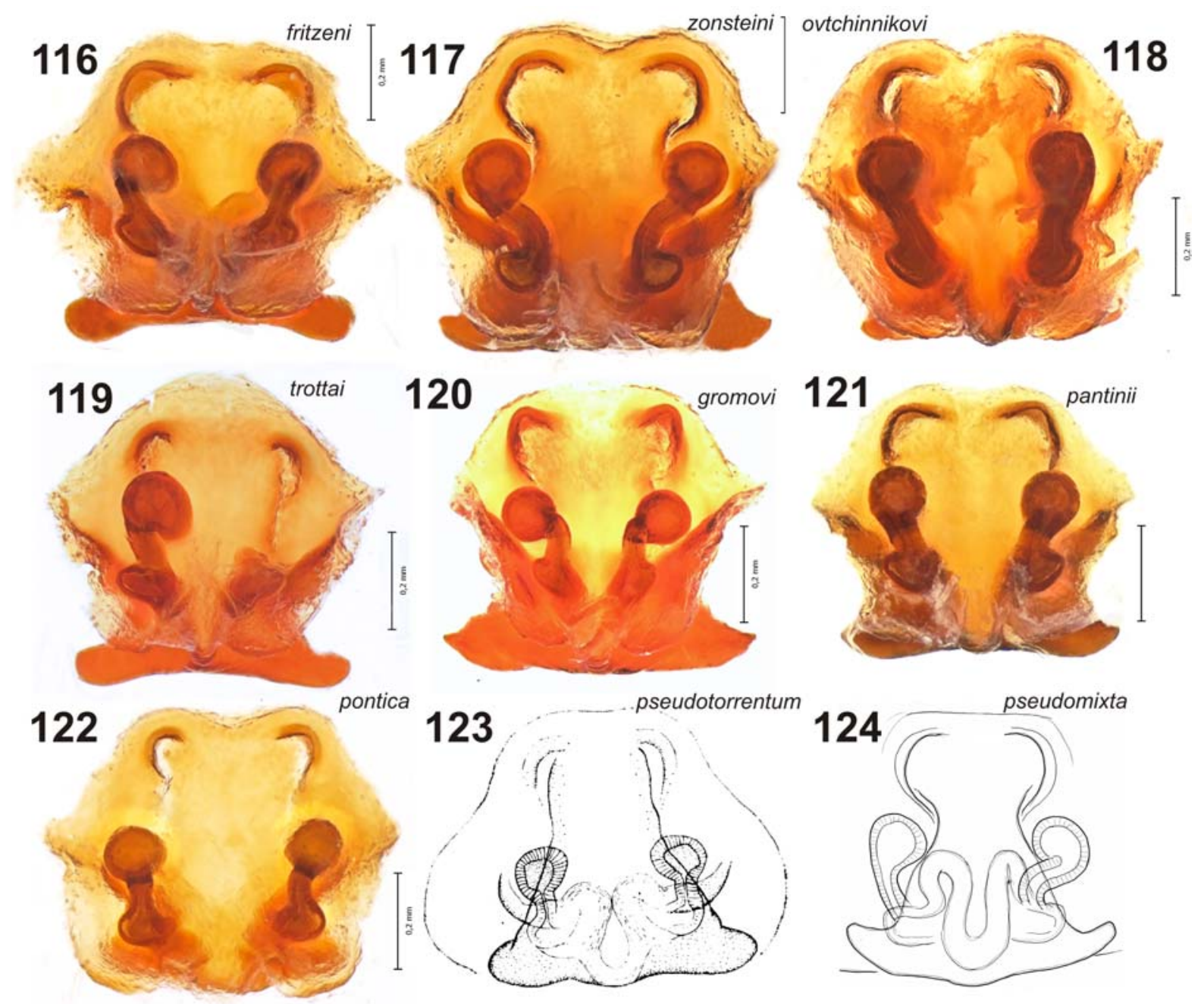

Figs 116-124. Dorsal view of epigyne of Pardosa fritzeni sp.n. (116), P. zonsteini sp.n. (117), P. ovtchinnikovi sp.n. (118), P. trottai sp.n. (119), $P$. gromovi sp.n. (120), P. pantinii sp.n. (121), P. pontica (122), P. pseudotorrentum (123) and P. pseudomixta (124): 123 after Miller \& Buchar [1972], 124 - after Marusik \& Fritzén [2009], not to scale.

Рис. 116-124. Эпигина (сверху) Pardosa fritzeni sp.n. (116), P. zonsteini sp.n. (117), P. ovtchinnikovi sp.n. (118), P. trottai sp.n. (119), P. gromovi sp.n. (120), P. pantinii sp.n. (121), P. pontica (122), P. pseudotorrentum (123) и P. pseudomixta (124): 123 - по Miller \& Buchar [1972], 124 — по Marusik \& Fritzén [2009], не в масштабе.

the femur. Leg I length: $2.3+1.08+1.97+1.94+1.28$. Leg I spination: femur d3 p2 r2, patella p1 r0, tibia p2 r2 v2-2, metatarsus p1 r1 v2-2. Epigyne and vulva as in Figs 112, 121.

DISTRIBUTION. $P$. pantinii sp.n. is known only from the type locality, the village of Dzhirgatal in the south-west of Tajikistan (Fig. 126).

Pardosa pontica (Thorell, 1875)

Figs 8, 17, 27, 37, 48, 61, 67, 73, 79, 85, 99, 104, $113,122,125$.

P. p.: Tongiorgi, 1966b: 351, f. 10-11, 24 (О'ㅇ).

P. p.: Fuhn \& Niculescu-Burlacu, 1971: 118, f. 53a-c ( $\left(0^{7}+\right)$

P. p.: Zyuzin \& Logunov, 2000: 316, f. 40-42 ((O) 9 ).

For a complete list of references see Platnick [2012].

MATERIAL EXAMINED. Turkmenistan, $10^{7} 19$ (ZMMU)West Kopetdagh Mountain Range, Kara-Kala $\left(38^{\circ} 25^{\prime}\right.$ $50.46^{\prime \prime} \mathrm{N} 56^{\circ} 16^{\prime} 49.69^{\prime \prime} \mathrm{E}$ ), 29.03.1993 (S.V. Ovtchinnikov); $10^{7}$
(SZMN: SZM 001.3740) Aidere (38 $\left.24^{\prime} 2^{\prime \prime} 56^{\circ} 44^{\prime} 37^{\prime \prime} \mathrm{E}\right)$, 18.03.8.04.1979 (V.Ya. Fet); 1 O $^{7}$ (SZMN: SZM 001.3737) Kopetdagh, Parkhai, vegetable garden $\left(38^{\circ} 30^{\prime} \mathrm{N} 56^{\circ} 12^{\prime} \mathrm{E}\right), 14.06 .1981$ (V.Y. Fet); $1 \sigma^{7}$ (SZMN: SZM 001.3744) Kopetdagh Mts., Parkhai, KaraKala $\left(38^{\circ} 25^{\prime} 50.46^{\prime \prime} \mathrm{N} 56^{\circ} 16^{\prime} 49.69^{\prime \prime} \mathrm{E}\right), 6.07 .1981$ (V.Ya. Fet).

DIAGNOSIS. Pardosa pontica is closely related to $P$. agrestis. The differences between these species have been well illustrated by Zyuzin \& Logunov [2000]. Males of $P$. pontica are similar to $P$. pseudomixta in terms of habitus and size, but the two species can be distinguished by the different shape of the terminal apophysis, which is stouter and squared in $P$. pontica (cf. Figs 67, 79 and 92). In addition, the black apical part of tarsi I seems to be reduced in this species. $P$. pontica can be easily separated from $P$. pseudotorrentum by the coloration of leg I (cf. Figs 47 and 48,61 and 62) and by the shape of the terminal apophysis (cf. Figs 28 and 67, 79). This species is distinguished from other Middle 


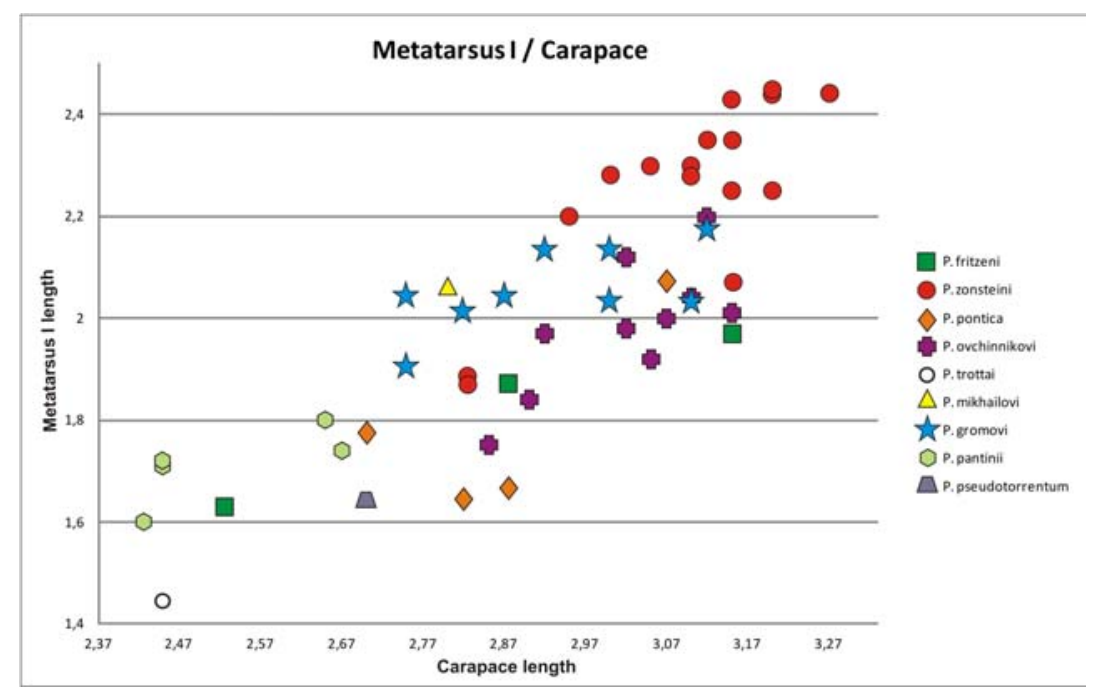

Fig. 125. Diagram showing metatarsus I / carapace length ratio in males of eight species.

Рис. 125. Диаграмма, показывающая соотношение длины предлапки I и карапакса у самцов восьми видов.

Asian monticola-group males by the black tip of tarsi I, having a stronger and stouter terminal apophysis, and by the lighter ventral surface of the palpal tibia. Females of this species can just about be distinguished from other Middle Asian monticola-group species by the shape of septum, which is slightly longer than wide and rounded posteriorly (Fig. 113).

DESCRIPTION. The species was well described by Tongiorgi [1966b] and Zyuzin \& Logunov [2000]. Spination of legs is shown in Tables 1 and 2.

DISTRIBUTION. $P$. pontica is distributed from Bulgaria [Helsdingen, 2010] to western Turkmenistan [Zyuzin \& Logunov, 2000].

Pardosa pseudotorrentum Miller et Buchar, 1972

Figs 9, 14, 26, 28, 38, 47, 62, 114, 123.

P. p. Miller \& Buchar, 1972: 391, f. 20-25 ( ( $\left.{ }^{7}+\right)$.

MATERIAL EXAMINED. Afghanistan: Holotype 9 (NMPR P6E-2931) Hindukuš, Údolí Tiriè, 4100 m, 5.07.1967. Paratypes $1 \sigma^{7}$ (NMPR: P6E-2929) Hindukuš, Údolí Tiriè, 4100m, nad základním táborem, 4.07.1967; 1 ㅇ (NMPR: P6E-2930) Hindukuš, Údoli Tiriè, 1.trávník pod táborem, $4000 \mathrm{~m}$, smyk, 7.07.1967.

DIAGNOSIS. Males of $P$. pseudotorrentum are very similar to males of $P$. ovtchinnikovi sp.n. in terms of habitus and leg I coloration, but the two species can be easily separated by the shape of the terminal apophysis, which is stumpy and triangular in $P$. pseudotorrentum and thin and narrow in $P$. ovtchinnikovi sp.n. (cf. Figs 28 and 69, 81).

The dark habitus, brown colour of leg I and the shape of the terminal apophysis distinguish males of this species from all other Middle Asian P. monticola species-group males.

$P$. pseudotorrentum females have no specific characters that permit their differentiation from other group members.

DESCRIPTION. This species was well described by Miller \& Buchar [1972]. Leg spination patterns for both sexes are shown in Tables 1 and 2 .
DISTRIBUTION. P. pseudotorrentum is known only from the type locality, the Hindu-Kush mountains in Afghanistan (Fig. 126).

Pardosa pseudomixta Marusik et Fritzén, 2009

Figs 10, 29, 46, 63, 92-93, 115, 124.

P. mixta: Chen \& Song, 2002: 342, f. 4-11 ( $\sigma^{7}$, misidentified). P. p. Marusik \& Fritzén, 2009: 412, f. 1A-C, E-F, 2A-B, F-J, 3B-D, G, 4B, E-G, J ( $\left.\sigma^{2}+\right)$.

DIAGNOSIS. $P$. pseudomixta is closely related to $P$. pontica, but males of the two species can be easily separated by the shape of the terminal apophysis, which is thin and pointed in the former and stout and squared in the latter (cf. Figs 67, 79 and 92). P. pseudomixta males are readily distinguished from other Middle Asian $P$. monticola-group species by the different coloration of leg I (Figs 46, 63).

Females of this species have insufficient characters to clearly separate them from other Middle Asian $P$. monticola-group females.

DESCRIPTION. P. pseudomixta was described comprehensively by Marusik \& Fritzén [2009].

DISTRIBUTION. $P$. pseudomixta seems to be restricted to northern Xinjiang, China [Marusik \& Fritzén, 2009].

\section{Discussion}

Although species identification in the Pardosa monticola-group is rather difficult for European and Caucasian taxa because of similarities in the palpal structure of males, variability in the epigynes of females, and high species diversity, the Middle Asian species (especially males) can be relatively easily identified on the basis of coloration/pattern and/or leg I characters: spination, coloration and type of pubescence (arrangement of long and short hairs on tarsi-metatarsi, white hairs on patella of the palp). In Europe and adjacent 


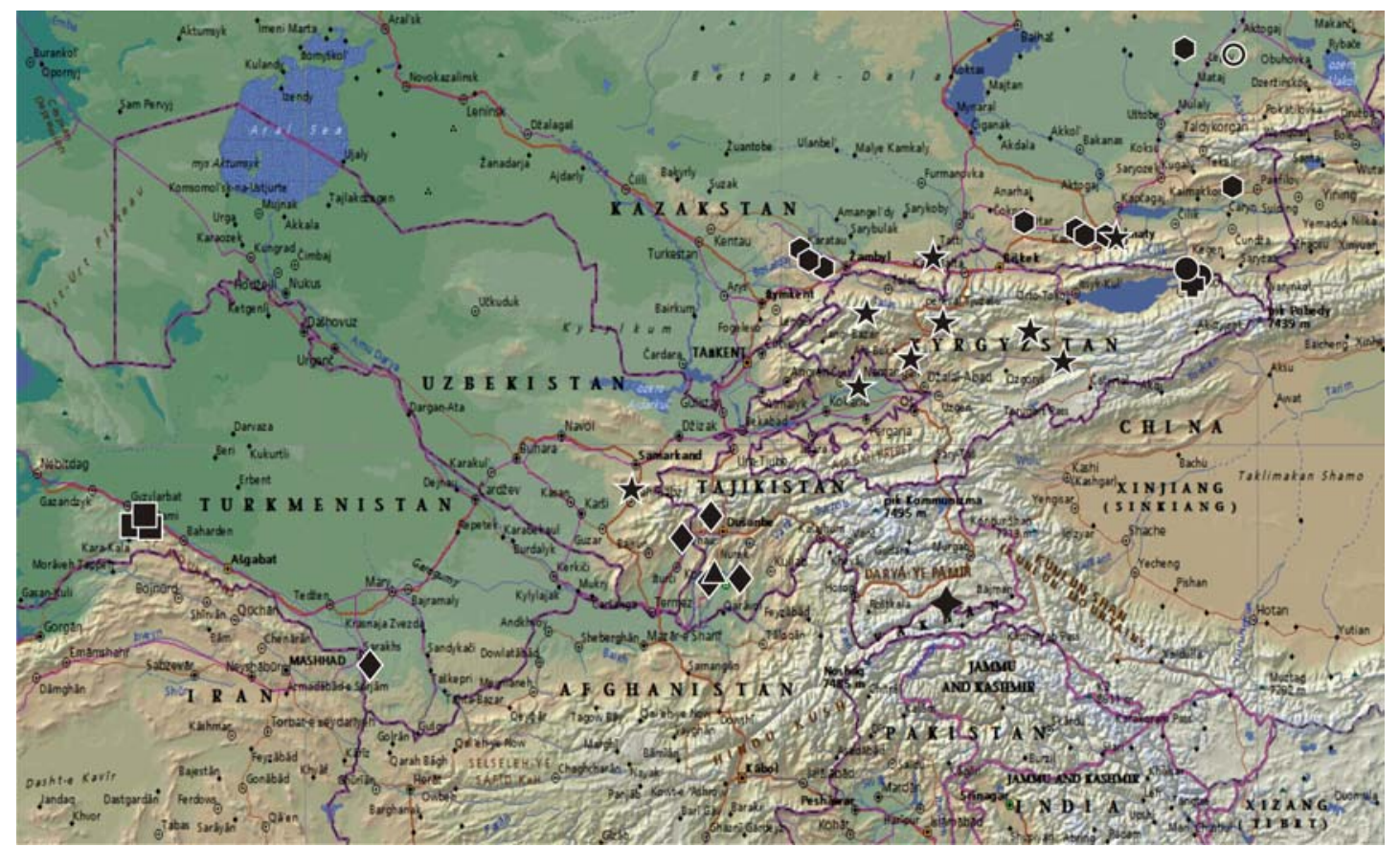

Fig. 126. Distribution of the Pardosa monticola-group species in Middle Asia: $\bullet$ P. fritzeni sp.n., $\star P$. zonsteini sp.n., $\diamond P$. ovtchinnikovi sp.n., + P. trottai sp.n., О P. mikhailovi sp.n., - P. gromovi sp.n., $\boldsymbol{\Delta}$ P. pantinii sp.n., $\square$ P. pontica, $\downarrow$ P. pseudotorrentum (approximately).

Рис. 126. Распространение видов группы Pardosa monticola в Средней Азии, в т.ч.: P. pseudotorrentum - приблизительно.

Turkey only a few species can be easily distinguished on the basis of leg I characters (P. plumipes (Thorell, 1875), P. mixta (Kulczyński, 1887), P. ilgunensis Nosek, 1905 (= P. ilguenensis) and P. agrestis purbeckensis F.O. Pickard-Cambridge, 1895) [cf. Tongiorgi, 1966b]. Few species can be recognized due to their size (cf. Fig. 125).

Females of Middle Asian species seem to follow the general trend of intraspecific epigynal variation seen in other monticola-group species. Only a few of the species can be identified by their habitus and the structures of the epigyne and vulva.

According to our studies, the spination pattern of the first pair of legs is useful for distinguishing Pardosa species, although a small degree of variation in spine position and presence has been noted. Differences in spination on the first pair of legs in males (Tab. 1) can be observed especially on the metatarsus (one or two spines in prolateral and/or in retrolateral positions), and the femur (two or three retrolateral spines). The tibia and patella of the first pair of legs have a more uniform spination; only $P$. fritzeni $\mathrm{sp}$. n. seems to be differ in that some specimens of this species have no spines on the patella and only one prolateral/retrolateral spine on the tibia instead of the normal two.

Females (Tab. 2) also exhibit differences in leg I spination, especially on the tibia ( $P$. fritzeni sp.n., $P$. zonsteini sp.n.) and the metatarsus (P. pontica, $P$. trottai sp.n.), whereas the femur and patella seem to be more uniform. However, the small number of female samples available in this study do not permit confirmation of species specific differences. Indeed, the variation may be even greater than that noted here.

None of the West Palaeartic species previously reported for Middle Asia were found during this survey, except for P. pontica. Pardosa mixta reported from eastern Uzbekistan [Charitonov, 1969] in fact belongs to P. zonsteini sp.n. Pardosa agrestis records can be referred to $P$. pontica because of the black tip of tarsi I, which the two species have in common. The record of $P$. plumipes probably refers to $P$. zonsteini sp.n., the two species have similar long hairs on the tarsi-metatarsi I (cf. Figs 49 and 51). It is likely that the record of $P$. palustris by Kroneberg [1875] refers also to $P$. zonsteini sp.n. or $P$. gromovi sp.n., because the author indicated long hairs on tarsi I that are absent in males of $P$. palustris.

ACKNOWLEDGEMENTS. The authors thank Alexander V. Gromov for providing us with more material from Kazakhstan and for his essential help to find the correct location of localities, to Galina Azarkina for loaning material from the Siberian Zoological Museum of Novosibirsk, Russia and to Torbjörn Kronestedt for consultations about the history of the P. monticola-group name. We are also obliged to K.G. Mikhailov who provided us with information about all records of Pardosa monticola-group species in Middle Asia. The manuscript was kindly reviewed by T. Kronestedt and M.M. Kovblyuk. English of an earlier draft was checked and edited by David Penney. This work was supported in part by the Russian Foundation for Basic Research (grants \#\# 110401716 and 12-04-01548) and by the Finnish CIMO fellowship. 
Table 1. Spination of leg I in males.

Таблица 1. Вооружение ноги I самца.

\begin{tabular}{|l|c|c|c|c|}
\hline \multicolumn{1}{|c|}{ Spination } & Femur & Patella & Tibia & Metatarsus \\
\hline P. fritzeni sp.n. & $\mathrm{d} 3 \mathrm{p} 2 \mathrm{r} 2$ & $\mathrm{p} 1(0) \mathrm{r} 1(0)$ & $\mathrm{p} 2(1) \mathrm{r} 2(1) \mathrm{v} 2-2$ & $\mathrm{p} 1 \mathrm{r} 1 \mathrm{v} 2-2$ \\
\hline P. zonsteini sp.n. & $\mathrm{d} 3 \mathrm{p} 2 \mathrm{r} 2$ & $\mathrm{p} 1 \mathrm{r} 1 \mathrm{r}$ & $\mathrm{p} 2 \mathrm{r} 2 \mathrm{v} 2-2$ & $\mathrm{p} 2(1) \mathrm{r} 2(1) \mathrm{v} 2-2$ \\
\hline P. pontica & $\mathrm{d} 3 \mathrm{p} 2 \mathrm{r} 2$ & $\mathrm{p} 1 \mathrm{r} 1$ & $\mathrm{p} 2 \mathrm{r} 2 \mathrm{v} 2-2$ & $\mathrm{p} 2 \mathrm{r} 1 \mathrm{v} 2-2$ \\
\hline P. ovtchinnikovi sp.n. & $\mathrm{d} 3 \mathrm{p} 2 \mathrm{r} 2$ & $\mathrm{p} 1 \mathrm{r} 1$ & $\mathrm{p} 2 \mathrm{r} 2 \mathrm{v} 2-2$ & $\mathrm{p} 1 \mathrm{r} 1 \mathrm{v} 2-2$ \\
\hline P. trottai sp.n. & $\mathrm{d} 3 \mathrm{p} 2 \mathrm{r} 3(2)$ & $\mathrm{p} 1 \mathrm{r} 1$ & $\mathrm{p} 2 \mathrm{r} 2 \mathrm{v} 2-2$ & $\mathrm{p} 2 \mathrm{r} 1 \mathrm{v} 2-2$ \\
\hline P. mikhailovi sp.n. & $\mathrm{d} 3 \mathrm{p} 2 \mathrm{r} 3$ & $\mathrm{p} 1 \mathrm{r} 1$ & $\mathrm{p} 2 \mathrm{r} 2 \mathrm{v} 2-2$ & $\mathrm{p} 2 \mathrm{r} 1 \mathrm{v} 2-2$ \\
\hline P. gromovi sp.n. & $\mathrm{d} 3 \mathrm{p} 2 \mathrm{r} 2(1)$ & $\mathrm{p} 1 \mathrm{r} 1$ & $\mathrm{p} 2 \mathrm{r} 2 \mathrm{v} 2-2$ & $\mathrm{p} 1 \mathrm{r} 1 \mathrm{v} 2-2$ \\
\hline P. pantinii sp.n. & $\mathrm{d} 3 \mathrm{p} 2 \mathrm{r} 2$ & $\mathrm{p} 1 \mathrm{r} 1$ & $\mathrm{p} 2 \mathrm{r} 2 \mathrm{v} 2-2$ & $\mathrm{p} 2 \mathrm{r} 1 \mathrm{v} 2-2$ \\
\hline P. pseudotorrentum & $\mathrm{d} 3 \mathrm{p} 2 \mathrm{r} 2$ & $\mathrm{p} 1 \mathrm{r} 1$ & $\mathrm{p} 2 \mathrm{r} 2 \mathrm{v} 2-2$ & $\mathrm{p} 1 \mathrm{r} 1 \mathrm{v} 2-2$ \\
\hline P. pseudomixta & $\mathrm{d} 3 \mathrm{p} 2 \mathrm{r} 2$ & $\mathrm{p} 1 \mathrm{r} 1$ & $\mathrm{p} 2 \mathrm{r} 2 \mathrm{v} 2-2$ & $\mathrm{p} 2 \mathrm{r} 1 \mathrm{v} 2-2$ \\
\hline
\end{tabular}

Table 2. Spination of leg I in females.

Таблица 2. Вооружение ноги I самки.

\begin{tabular}{|l|c|c|c|c|}
\hline \multicolumn{1}{|c|}{ Spination } & Femur & Patella & Tibia & Metatarsus \\
\hline P. fritzeni sp.n. & $\mathrm{d} 3 \mathrm{p} 2 \mathrm{r} 2$ & $\mathrm{p} 1 \mathrm{r} 0$ & $\mathrm{p} 2 \mathrm{r} 1 \mathrm{v} 2-2$ & $\mathrm{p} 1 \mathrm{r} 1 \mathrm{v} 2-2$ \\
\hline P. zonsteini sp.n. & $\mathrm{d} 3 \mathrm{p} 2 \mathrm{r} 2$ & $\mathrm{p} 1 \mathrm{r} 0$ & $\mathrm{p} 1 \mathrm{r} 1 \mathrm{v} 2-2$ & $\mathrm{p} 1 \mathrm{r} 1 \mathrm{v} 2-2$ \\
\hline P. pontica & $\mathrm{d} 3 \mathrm{p} 2 \mathrm{r} 2$ & $\mathrm{p} 1 \mathrm{r} 0$ & $\mathrm{p} 2 \mathrm{r} 2 \mathrm{v} 2-2$ & $\mathrm{p} 2 \mathrm{r} 1 \mathrm{v} 2-2$ \\
\hline P. ovtchinnikovi sp.n. & $\mathrm{d} 3 \mathrm{p} 2 \mathrm{r} 2$ & $\mathrm{p} 1 \mathrm{r} 0$ & $\mathrm{p} 2 \mathrm{r} 2 \mathrm{v} 2-2$ & $\mathrm{p} 1 \mathrm{r} 1 \mathrm{v} 2-2$ \\
\hline P. trottai sp.n. & $\mathrm{d} 3 \mathrm{p} 2 \mathrm{r} 2$ & $\mathrm{p} 1 \mathrm{r} 0$ & $\mathrm{p} 2 \mathrm{r} 2 \mathrm{v} 2-2$ & $\mathrm{p} 2 \mathrm{r} 1 \mathrm{v} 2-2$ \\
\hline P. mikhailovi sp.n. & - & - & - & - \\
\hline P. gromovi sp.n. & $\mathrm{d} 3 \mathrm{p} 2 \mathrm{r} 2$ & $\mathrm{p} 1 \mathrm{r} 0$ & $\mathrm{p} 2 \mathrm{r} 2 \mathrm{v} 2-2$ & $\mathrm{p} 1(2) \mathrm{r} 1 \mathrm{v} 2-2$ \\
\hline P. pantinii sp.n. & $\mathrm{d} 3 \mathrm{p} 2 \mathrm{r} 2$ & $\mathrm{p} 1 \mathrm{r} 0$ & $\mathrm{p} 2 \mathrm{r} 2 \mathrm{v} 2-2$ & $\mathrm{p} 1 \mathrm{r} 1 \mathrm{v} 2-2$ \\
\hline P. pseudomixta & - & - & - & - \\
\hline P. pseudotorrentum & $\mathrm{d} 3 \mathrm{p} 2 \mathrm{r} 2$ & $\mathrm{p} 1 \mathrm{r} 0$ & $\mathrm{p} 2 \mathrm{r} 2 \mathrm{v} 2-2$ & $\mathrm{p} 1 \mathrm{r} 1 \mathrm{v} 2-2$ \\
\hline
\end{tabular}

\section{References}

Charitonov D.E. 1969. [Materials to the spider fauna of USSR] // Uchenyye zapiski Permskogo gosudarstvennogo universiteta imeni A.M. Gorkogo. T.179. P.59-133 [in Russian]

Dahl F. 1908. Die Lycosiden oder Wolfspinnen Deutschlands und ihre Stellung im Haushalt der Natur // Nova Acta. Caes. Leop.Carol. Acad. Bd.88. Nr.3. S.175-678.

Chen J., Song D.X. 2002. A new species and a new record of monticola group of the genus Pardosa from China (Araneae, Lycosidae) // J. Shanxi Univ., Nat. Sci. Ed. J. Vol.25. P.341-344.

Dondale C.D., Redner J.H. 1990. The insects and arachnids of Canada, Part 17. The wolf spiders, nurseryweb spiders, and lynx spiders of Canada and Alaska, Araneae: Lycosidae, Pisauridae, and Oxyopidae // Research Branch, Agriculture Canada, Publication No.1856. 383 pp.

Fuhn I.E., Niculescu-Burlacu F. 1971. Fam. Lycosidae // Fauna Republicii Socialiste România (Arachnida) Vol.5. No.3. P.1-253.

Helsdingen P.J. 2011. Fauna Europaea: Araneae. Fauna Europaea version 2.4, on-line at http://www faunaeur.org/

Kroneberg A. 1875. [Spiders - Araneae] // Fedtschenko A.P. (ed.). Puteshestvie v Turkestan. Izvestiya Obshchestva lyubitelei estestvoznaniya, antropologii I etnografii. T.19. No.3. P.i-iv, $1-55,5$ color tabs. [in Russian].

Locket G.H., Millidge A.F. 1951. British spiders. London: Ray Society. Vol.1. 310 pp.

Marusik Yu.M., Fritzén N.R. 2009. A new wolf spider species in the Pardosa monticola-group (Araneae: Lycosidae) from Xinjiang, China // J. Nat. Hist. Vol.43. P.411-422.

Marusik Yu.M., Ballarin F. 2011. Redescription of the Himalaian Pardosa flavisterna Caporiacco, 1935 (Aranei: Lycosidae) with notes of the Pardosa nebulosa species-group // Proc. Zool. Inst., Russian Academy of Sciences. Vol.315. No.1. P.63-69.

Miller F., Buchar J. 1972. Einige neue Spinnenarten (Araneae) aus dem Hindukusch // Acta Univ. Carol.-Biol. (for 1970). S.383-398.
Mikhailov K.G. 1997. Catalogue of the spiders of the territories of the former Soviet Union (Arachnida, Aranei). Moscow: Zoological Museum, Moscow State Univiversity. 416 pp.

Pickard-Cambridge O. 1885. Araneida // Scientific results of the second Yarkand Mission. Calcutta. 115 pp.

Platnick N.I. 2012. The World Spider Catalog, Version 12.5. American Museum of Natural History, on-line at http://research. amnh.org/iz/spiders/catalog/

Roewer C.F. 1955. Die Araneen der Österreichischen Iran-Expedition 1949/50 // Sitzber. Österr. Akad. Wiss. I. Bd.164. S.751-782.

Roewer C.F. 1959. Araneae Lycosaeformia II (Lycosidae) // Exploration du Parc National de l'Upemba Mission G.F. De Witte. Fasc.55. P.1-518.

Schmidt P. 1895. Beitrag zur Kenntnis der Laufspinnen (Araneae Citigradae Thor.) Russlands // Zool. Jahrb., Syst. Bd.8. P.439484.

Thorell T. 1872. Remarks on synonyms of European spiders. Upsala. Part III. P.229-374.

Tongiorgi P. 1966a. Italian wolf spiders of the genus Pardosa (Araneae: Lycosidae) // Bulletin of the Museum Comparative Zoology, Harvard. Vol.134. P.275-334.

Tongiorgi P. 1966b. Wolf spiders of the Pardosa monticola group (Araneae: Lycosidae) // Bull. Mus. Comp. Zool., Harvard. Vol.134. P.335-359.

Wiebes J.T. 1959. The Lycosidae and Pisauridae (Araneae) of the Netherlands // Zoöl. Verh. Vol.42. P.1-78.

Zyuzin A.A. 1979. A taxonomic study of Palaearctic spiders of the genus Pardosa (Aranei, Lycosidae). Part 1. The taxonomic structure of the genus // Entomologicheskoe Obozrenie. Vol.58. No.2. P.431-447 [in Russian].

Zyuzin A.A., Logunov D.V. 2000. New and little-known species of the Lycosidae from Azerbaihan, the Caucasus (Araneae, Lycosidae) // Bull. Brit. Arachnol. Soc. Vol.11. Pt.8. P.305-319.

Responsible editor K.G. Mikhailov 